
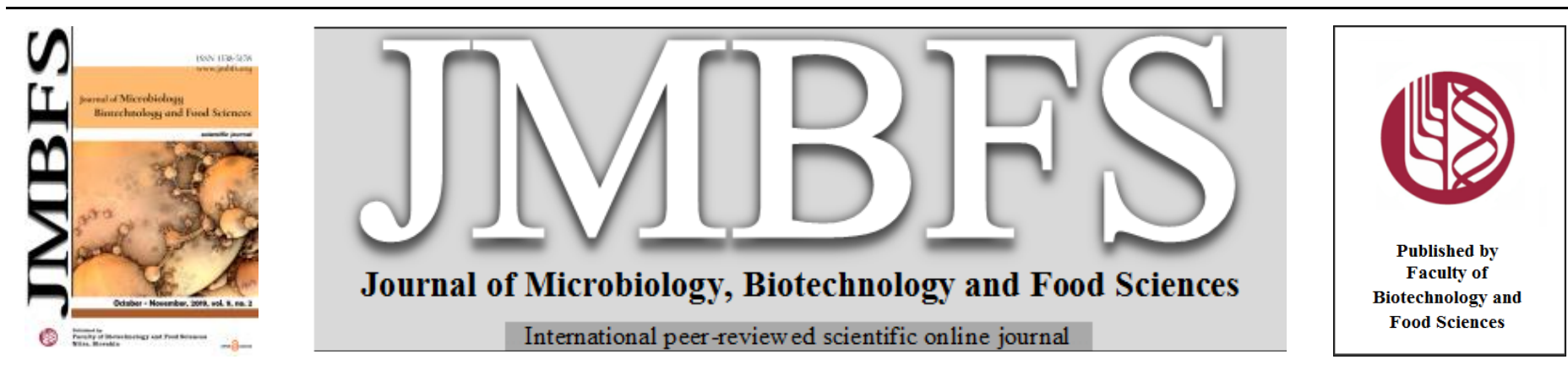

\title{
AMELIORATION WITH TITANIUM DIOXIDE NANOPARTICLE FOR REGULATION OF OXIDATIVE STRESS IN MAIZE (Zea mays L.)
}

\author{
Bipul Sarkar ${ }^{l}$, Arnab Kumar De ${ }^{1}$, Indraneel Saha ${ }^{1}$, Arijit Ghosh ${ }^{1}$, Subhas Chandra Debnath ${ }^{2}$, Malay Kumar Adak $^{1 *}$
}

Address(es): Dr. Malay Kumar Adak

${ }^{1}$ University of Kalyani, Faculty of Science, Department of Botany, Kalyani-741235, West Bengal, India. Ph-+91-9432418218.

${ }^{2}$ University of Kalyani, Faculty of Science, Department of Chemistry, Kalyani-741235, West Bengal, India.

*Corresponding author: mkadak09@gmail.com

doi: 10.15414/jmbfs.2019.9.2.320-329

\section{ARTICLE INFO}

Received 2. 4. 2019

Revised 13. 6. 2019

Accepted 20. 6. 2019

Published 1. 10. 2019

Regular article OPEN $\partial$ ACCESS

\begin{abstract}
In the present experiment, Zea mays $\mathrm{L}$. was evaluated for its $\mathrm{C}_{4}$ modality through oxidative stress responses. Moreover, under variable concentrations $(0,50,100 \mu \mathrm{M})$ of hydrogen peroxide, the impacts were variable and modulated with titanium dioxide nanoparticle $\left(\mathrm{TiO}_{2}-\mathrm{NP}\right)$. Plants scored with elevated concentrations of $\mathrm{H}_{2} \mathrm{O}_{2}$ and superoxide $\left(\mathrm{O}_{2}{ }^{-}\right)$maximum by $1.31 \& 1.52$-fold respectively over $0 \mu \mathrm{M} \mathrm{H}_{2} \mathrm{O}_{2}$. TiO ${ }_{2}$ - $\mathrm{NP}$ recovered those maximums with $8.69 \& 7.89 \%$ as compared to control plants. The effects of $\mathrm{H}_{2} \mathrm{O}_{2}$ were moderated

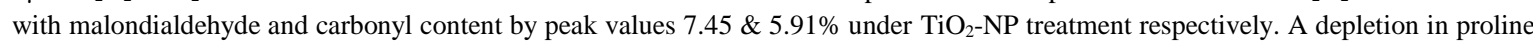
content recorded under $\mathrm{H}_{2} \mathrm{O}_{2}$ stress but recovered through highest 1.23-fold with $\mathrm{TiO}_{2}-\mathrm{NP}$ application. $\mathrm{TiO}_{2}-\mathrm{NP}$ recorded NADP-ME activities up-regulated in concentration gradient of $\mathrm{H}_{2} \mathrm{O}_{2}$. Oxidative exposure was also documented by in-vivo detection of $\mathrm{H}_{2} \mathrm{O}_{2}$ and $\mathrm{O}_{2}$. by 3,3'-diaminobenzidine and nitroblue tetrazolium staining. For the anti-oxidative cascades superoxide dismutase activity had induced by 1.42 -fold under $\mathrm{H}_{2} \mathrm{O}_{2}$ when pre-treated with $\mathrm{TiO}_{2}-\mathrm{NP}$. However, glutathione reductase activity was differentially modulated under $\mathrm{H}_{2} \mathrm{O}_{2}$ through interaction with $\mathrm{TiO}_{2}-\mathrm{NP}$. Activity of guaiacol peroxidase was significantly up-regulated by 1.07 -fold when $\mathrm{TiO}_{2}-\mathrm{NP}$ applied. The inductions of oxidative stress recorded more evident when a distinct polymorphism for GPX protein resolved variations in band intensities, but not in number. Activity of catalase experience a down-regulated trend all through the $\mathrm{H}_{2} \mathrm{O}_{2}$ exposure and had significant sensitivity to $\mathrm{TiO}_{2}-\mathrm{NP}$. The results depict the nature and reactivity of $\mathrm{C}_{4}$ modules under oxidative stress that would be the selection pressures and that might be modulated with $\mathrm{TiO}_{2}-\mathrm{NP}$ application
\end{abstract}

Keywords: $\mathrm{TiO}_{2}$-nanoparticle; Oxidative stress, Anti-oxidant enzymes, Malic enzyme, Maize

\section{INTRODUCTION}

In $\mathrm{C}_{4}$ system the $\mathrm{CO}_{2}$ concentration mechanism empowers with an added advantage towards abiotic stress tolerance of plants. The refixation of $\mathrm{CO}_{2}$ out of cellular respiration including photorespiration is a benefit for $\mathrm{C}_{4}$ plants through partitioning of carbon more towards the storage compounds (Bauwe, 2010). Still, there recorded a significant variation in loss of carbon through photorespiration in $\mathrm{C}_{3}$ species which is literally unavoidable. The storage compounds derived from photosynthesis includes structural carbohydrates, compatible solutes, secondary metabolites etc. All these may be well supported with in-built or induced physiological responses under stress. A higher value of water use efficiency could support the osmotic stability of $\mathrm{C}_{4}$ plants which is perturbed in almost abiotic stresses (Raven et al., 2004). The higher light compensation points of $\mathrm{C}_{4}$ plants minimizes the photo damages in such a way that photosynthetic photon flux density must not be compromised. Therefore, besides from photo-oxidative stress, $\mathrm{C}_{4}$ species are expected to be more adaptive against any kind of stress than $\mathrm{C}_{3}$ (Yamori et al., 2014). With this, $\mathrm{C}_{4}$ species have been its embracing with xenobiotics and other oxidative stress in plants than $\mathrm{C}_{3}$. Few of those, however, important industrial pollutants (like $\mathrm{H}_{2} \mathrm{O}_{2}$ ) are quite noxious to plants in perturbance of cellular redox. In consequence of the above, oxidative stress is being established. $\mathrm{H}_{2} \mathrm{O}_{2}$, not a free radical is perceived in plants with dual modes: an inducer of cellular responses as well as a de-generative moiety over the tolerable concentration (Quan et al., 2008). Evidences reveal that enhanced concentration of $\mathrm{H}_{2} \mathrm{O}_{2}$ disrupts the plants' metabolism in $\mathrm{C}_{3}$ plant, but may be adjusted for $\mathrm{C}_{4}$ plants (Stepien $\boldsymbol{\&}$ Klobus, 2005). It is the precise concentration of $\mathrm{H}_{2} \mathrm{O}_{2}$ that may develop an antioxidation cascades through enzymatic as well as non-enzymatic paths (Ahmad et al., 2008). In the present experiment, Zea mays $\mathrm{L}$, an established $\mathrm{C}_{4}$ syndrome practiser has been evaluated from the viewpoints of oxidative stress with inputs of chemical elicitors. The chemical elicitation is a form of allelopathy where any residues either endogenous or exogenous in nature would be supportive in plant responses. These responses may not be necessarily supportive to plants with its normal pace of metabolism but also to develop few other metabolic fluxes in stress tolerance (Thaler et al., 1999). Elicitors may include few growth regulators, simple inorganic salts, secondary metabolites etc. Moderation of plant responses by chemical elicitations is accomplished through two basic paths. Adjustment of osmotic status or cellular hydration, the first and sustenance of biological redox would the second. Thus, bioaccumulations of proline are a reliable index for osmoticum along with few enzymes for $\mathrm{C}_{4}$ photosynthesis (Kavi Kishor \& Sreenivasulu, 2014). NADP-malic enzyme (NADP-ME) is such a $\mathrm{C}_{4}$ tissue specific protein which concentrates $\mathrm{CO}_{2}$ from organic acids in anaplerotic reactions. In another mode plants are much revised with different forms of antioxidations by chemical elicitations through both enzymatic and non-enzymatic paths (Almeselmani et al., 2006). To score oxidative exposure plant tissues are often evaluated with their specific reactions mostly the peroxidation types. Lipid peroxidation, protein oxidation, oxidised products of nucleic acids are quite common in plants response to oxidative burst (Das \& Roychoudhury, 2014). The antioxidative proteins are mostly induced with their de-novo synthesis by few elicitors as already reported in few $\mathrm{C}_{4}$ species. This was more established with the post translational modifications of those proteins under inductions of few chemicals. The antioxidative enzymes are also evoked with supplement of electron donors from few phenolic residues. Ascorbate, glutathione, guaiacol are most common to induced peroxidase activity in lysis of $\mathrm{H}_{2} \mathrm{O}_{2}$. Nanomaterials have been another scope for chemical elicitations in plant responses, particularly under abiotic stresses (Prasad et al., 2017). With the modern state-of-art metals and metalloids are extensively implicated with nano forms/structures and proved to be useful. In crop system, engineered nanoparticles (ENPs) from different metals/metalloids verified their efficiency in slow release fertilizer or amendments (Duhan et al., 2017). Likewise, an established and well useful nano-material, like $\mathrm{TiO}_{2}$ has been implicated to modulate the plant responses, however, varied in crop species (De et al., 2018) As earlier report, maize proved the selectivity for few hazardous metals for hyper-accumulation. This is more illustrated with the tolerance of those by an improved anti-oxidation (Baig et al., 2010). Therefore, the present scope of work, experiments deal with how and whether ENP with $\mathrm{TiO}_{2}$ has any modulation on 
such anti-oxidation in maize would be judicially worth.. With this support we hypothesised that $\mathrm{TiO}_{2}-\mathrm{NP}$ would be more realistic to modulate the anti-oxidation potential of maize when faced with oxidative stress inducing agent. $\mathrm{H}_{2} \mathrm{O}_{2}$ would one of those as documented earlier (Schützendübel et al., 2002). Thus, the present experiment is embodied with the illustration of some physiological responses in maize under varying concentrations of $\mathrm{H}_{2} \mathrm{O}_{2}$ and to monitor the effects of $\mathrm{TiO}_{2}$-NP thereon.

\section{MATERIAL AND METHODS}

\section{Experimental plant materia}

The experimental works were conducted in the laboratory of Plant Physiology and Plant Molecular Biology Research Unit, Department of Botany, University of Kalyani, Kalyani-741235, India. The maize seeds (cv. Kaveri 50) were collected from the local farmers. Initially seeds were thoroughly washed to remove all surface bound debris, surface sterilized by $0.01 \% \mathrm{HgCl}_{2}$ and finally sun dried Then seeds were allowed to germinate as described earlier (Sarkar et al., 2017) and after sprouting seedlings were allowed to grow for 15 days under contro condition of light, moisture content $(\geq 80 \%)$ and temperature $\left(30-35^{\circ} \mathrm{C}\right)$ in a growth chamber. Seedlings were transferred in nutrient solution of $1 / 4^{\text {th }}$ Murashige \& Skoog (Murashige \& Skoog, 1962) media in two sets and acclimatized for 2 days. This was followed by pre-treatment of $300 \mathrm{mg} / \mathrm{L} \mathrm{TiO}_{2}$ $\mathrm{NP}, \mathrm{pH} 7.5$ against one set as control $(0 \mathrm{mg} / \mathrm{L})$ for 3 days. $\mathrm{TiO}_{2}-\mathrm{NP}$ (particle size $<100 \mathrm{~nm}$ ) with stabilizing agent as cetyl trimethyl ammonium bromide (CTAB) was synthesised in Department of Chemistry, University of Kalyani, properly characterised with opto-physical properties and reported in earlier (De $\boldsymbol{e t}$ al. 2018). After 3 days of pre-treatment the sets were further divided into sub-sets with $1 / 4^{\text {th }}$ of the same media $\& \mathrm{pH}$ in addition of exogenous application of $\mathrm{H}_{2} \mathrm{O}_{2}$ concentrations: $0,50 \& 100 \mu \mathrm{M}$. The whole sets were transferred to norma conditions of growth chamber of light $900-1200 \mu \mathrm{Em}^{-2} \mathrm{~s}^{-1}, 37-38^{\circ} \mathrm{C}, 80-85 \%$ relative humidity. All the treatments were replicated thrice with seedlings in RBD design. On completion of treatment of 3 days plants were recovered, washed with distilled water, separated into root and shoot, preserved under liquid nitrogen and stored in $-80^{\circ} \mathrm{C}$ for further biochemical use.

\section{Biochemical analyses}

Biochemical analyses were performed from the shoot portion of the maize plant sample according to standard methods under various treatments condition.

\section{Determination of $\mathrm{H}_{2} \mathrm{O}_{2} \& \mathrm{O}_{2}^{--}$content}

$\mathrm{H}_{2} \mathrm{O}_{2}$ content was determined according to Velikova et al. (2000). $1.0 \mathrm{gm}$ of fresh tissue was thoroughly crushed under cold condition in $5 \mathrm{~mL}$ of $1 \%(\mathrm{w} / \mathrm{v})$ trichloroacetic acid (TCA) solution. The clear supernatant was achieved with centrifugation at $12000 \mathrm{x} \mathrm{g}$ for $15 \mathrm{~min}$ at $4^{\circ} \mathrm{C}$. The supernatant containing the hydrogen peroxide were preserved in cold condition by addition of $10 \mathrm{mM}$ phosphate buffer ( $\mathrm{pH} 7.0$ ) and 10mM potassium iodide (KI) solution. The set was incubated in dark for half an hour. The oxidized KI under $\mathrm{H}_{2} \mathrm{O}_{2}$ presence was measured spectrophotometrically at 390nm. Standard of $\mathrm{H}_{2} \mathrm{O}_{2}$ was prepared and the content of $\mathrm{H}_{2} \mathrm{O}_{2}$ was determined as $\mu \mathrm{M} / \mathrm{gm}$ f.wt.

For generation of $\mathrm{O}_{2}^{-*}$ content, $1.0 \mathrm{gm}$ fresh tissue was homogenised into fine powder with liquid nitrogen (Elstner \& Heupel, 1976) and extracted in a buffer of $60 \mathrm{mM}$ potassium phosphate buffer $(\mathrm{pH} 7.5)$ on centrifugation at $10000 \mathrm{x}$ g for $15 \mathrm{~min}$ at $4^{\circ} \mathrm{C}$. The supernatant was diluted with $65 \mathrm{mM}$ phosphate buffer $(\mathrm{pH}$ 7.8 ) and $10 \mathrm{mM}$ hydroxylamine hydrochloride at $25^{\circ} \mathrm{C}$ and kept for $30 \mathrm{~min}$. The reaction was stopped with $10 \mathrm{mM}$ sulphanilamide and $7 \mathrm{mM} \alpha$-naphthyl amine at $25^{\circ} \mathrm{C}$ for $20 \mathrm{~min}$. The absorbance was taken at 530 $\mathrm{nm}$ with the blank and the content was derived from a standard of $\mathrm{NO}_{2}{ }^{-}$.

\section{Histochemical detection of $\mathrm{H}_{2} \mathrm{O}_{2} \& \mathrm{O}_{2}{ }^{-}$}

In-vivo detection of ROS were done both from leaf and root samples. Leaves and roots were cut into uniform sizes and thoroughly washed with double distilled water and used for infiltration.

Accumulation of $\mathrm{H}_{2} \mathrm{O}_{2}$ was detected by in-vivo infiltration of 3'3'diaminobenzidine (DAB) as suggested by Thordal-Christensen et al. (1997) Freshly collected leaves from the treatment were infiltrated with $5 \mathrm{mM}$ freshly prepared DAB solution in phosphate buffer $(\mathrm{pH} 6.8)$. The sample in solution was kept for over-night in dark. First the $\mathrm{pH}$ of the buffer reduced to acidic condition ( $\mathrm{pH} 3.8$ ) and then adjusted to $\mathrm{pH} 6.8$ towards dissolving the DAB completely. On following day, leaves were maid colourless by removing the chlorophyll using lactic acid-glycerol-ethanol solution $(1: 1: 4-\mathrm{v} / \mathrm{v} / \mathrm{v})$ following gentle boiling in water-bath for 10-12 min. The distribution of hydrogen peroxide bound DAB products were visualized as brown patches and were digitally captured (Dewinter camera).

For the detection of superoxide ion $\left(\mathrm{O}_{2}^{--}\right)$within the leaf tissue, an incubation mixture with $50 \mathrm{mM}$ phosphate buffer containing $6 \mathrm{mM}$ Nitroblue tetrazolium (NBT) salt (pH 4.8) was used (Fryer et al., 2002). On overnight infiltration, the leaves were made transparent as mentioned above. Then the formazan complex with deep blue patches were captured as described above.

\section{Determination of MDA content}

For lipid peroxidation, the concentration of MDA was detected as suggested by Heath \& packer (1968) with slight modification. Under ice cold condition leaf tissues thoroughly homogenised on $80 \%$ ethanol. The debris were discarded on centrifugation under ice cold condition at $12000 \mathrm{x}$ g for $15 \mathrm{~min}$ and saved the supernatant. An aliquot of $1 \mathrm{~mL}$ was mixed with $20 \%$ TCA containing $0.5 \%$ Thiobarbituric acid (TBA). The mixture was reacted in a temperature of $95^{\circ} \mathrm{C}$ for $30-45 \mathrm{~min}$. The absorbance at 532 and $600 \mathrm{~nm}$ was recorded against blank in a UV-VIS spectrophotometer. The content of MDA was calculated and expressed as $\mathrm{nM} / \mathrm{gm}$ f.wt. using $155 \mathrm{mM}^{-1} \mathrm{~cm}^{-1}$ as extinction co-efficient of MDA.

\section{Determination of carbonyl content}

The carbonyl content of the leaf extract was done from $1.0 \mathrm{gm}$ of fresh leaf tissue suggested by Verbeke et al. (2000) and homogenised in 6\% sodium dodecyl sulphate (SDS) solution. The homogenate was incubated at $37^{\circ} \mathrm{C}$ for $30 \mathrm{~min}$ with freshly prepared $10 \mathrm{mM} 2$, 4-dinitrophenylhydrazine (DNPH) solution in $1.5 \mathrm{mM}$ TCA. The whole mixture was homogenised under constant stirring. By addition of $10 \%(\mathrm{w} / \mathrm{v})$ TCA solution under cold condition, it was de-proteinated. The coagulated proteins were re-extracted with $20 \%(\mathrm{w} / \mathrm{v})$ TCA solution. The pellet was washed with $2 \%(\mathrm{w} / \mathrm{v})$ diethyl ether followed by absolute alcohol. The absorbance was read at $360 \mathrm{~nm}$ upon resuspend the pellet in $0.2 \mathrm{M}$ phosphate buffer (pH 7.0). Using $530 \mathrm{M}^{-1} \mathrm{~cm}^{-1}$ as molar extinction co-efficient of DNPH, the carbonyl content was derived.

\section{Determination of Proline content}

Accumulation of proline content was analysed with the aqueous extract from 0.1 gm of fresh leaf tissue in $10 \mathrm{ml}$ of $3 \%$ sulphosalicylic acid solution. The supernatant was set from centrifugation at $10000 \times \mathrm{g}$ at $4^{\circ} \mathrm{C}$ for $15 \mathrm{~min}$. The supernatant was reacted with ninhydrin solution (dissolved in $0.2 \mathrm{M}$ citrate buffer (pH 5.4) with 0.8 gm stannous chloride and 2 gm ninhydrin which was initially dissolved in 100ml 2-methoxy ethanol.) The filtrate within this buffer was diluted by $1 \mathrm{ml}$ of glacial acetic acid and boiled for $30 \mathrm{~min}$ until the colour develops. The reaction was stopped on ice bath following constant stirring with $4 \mathrm{ml} 10 \%$ toluene. The aqueous toluene layer was aspirated and warmed gently. From the intensity of the colour at 520nm, the content of proline was estimated using a standard of proline according to Bates $\boldsymbol{e t}$ al. (1973). The concentration was expressed as $\mu \mathrm{M} / \mathrm{gm}$ f.wt.

\section{Assay of Nicotinamide adenine dinucleotide phosphate-malic enzyme (NADP-ME) activity}

The activity of NADP-malic enzyme (EC 1.1.1.40) (L-malate: NADPOxidoreductase) was assayed as suggested by Murmu et al. (2003) with slight modification. Initially the plant was harvested and fully expanded leaves were excised during day time pre-exposed 4 hours under sun rays. The leaves were kept in darkness for 1 hour. The leaf segments were initially incubated with $2 \mathrm{mM}$ bicarbonate solution and illuminated with saturating photosynthetic photon flux density (900-1000). After illumination the enzyme extract was made in $1 \mathrm{~mL}$ of extraction buffer containing $5 \mathrm{mM} \mathrm{MgCl}, 10 \mathrm{mM}$ EDTA, 5mM DTT, $1 \mu \mathrm{M}$ protease inhibitor Cocktail (Sigma-Aldrich), 1mM PMSF, 1\% PVP. The extract was centrifuged at $14000 \mathrm{x} \mathrm{g}$ at $4{ }^{\circ} \mathrm{C}$ for $15 \mathrm{~min}$. the supernatant was used as source of NADP-ME for the assay. The reaction mixture contains $15 \mathrm{mM}$ Tris$\mathrm{HCl}(\mathrm{pH} 8.0), 10 \mathrm{mM} \mathrm{MgCl} 2,0.5 \mathrm{mM} \mathrm{NADP}$ and $200 \mu \mathrm{L}$ of supernatant and the reaction was started by adding $5 \mathrm{mM}$ malate. The activity was assayed by reduction of NADP reading at $340 \mathrm{~nm}$ in UV-VIS spectrophotometer. The activity was expressed as nM NADPH produced/min/mg protein.

\section{Assay of anti-oxidative enzymes}

For the anti-oxidative enzymes fresh leaf samples were collected from each treatment and frozen with liquid nitrogen to grime properly. The samples were homogenized with ice cold extraction buffer containing $50 \mathrm{mM}$ phosphate buffer (pH 7.0), $5 \mathrm{mM} \mathrm{MgCl}_{2}, 1 \mathrm{mM}$ PMSF, $10 \mathrm{mM}$ EDTA, $1 \mu \mathrm{M}$ protease inhibitor Cocktail (Sigma-Aldrich). The homogenate was separated into supernatant by $14000 \mathrm{x} \mathrm{g}$ for $15 \mathrm{~min}$ at $4^{\circ} \mathrm{C}$. Supernatant containing protein was partially purified with $80 \%$ ammonium sulphate $\left(\left(\mathrm{NH}_{4}\right)_{2} \mathrm{SO}_{4}\right)$ cut. The recovered pellet of purified protein on overnight incubation at $4^{\circ} \mathrm{C}$ was recovered by centrifugation at $20000 \mathrm{x} \mathrm{g}$ for $15 \mathrm{~min}$ at $4^{\circ} \mathrm{C}$. Finally, the pellet was dissolved in dilution buffer of $25 \mathrm{mM}$ phosphate buffer (pH 7.0 ) with $1.5 \mathrm{mM}$ DTT, $2 \mu \mathrm{M}$ BSA and $0.1 \%$ SDS. This was used as enzyme extract for following assays (Sarkar et al., 2017). 


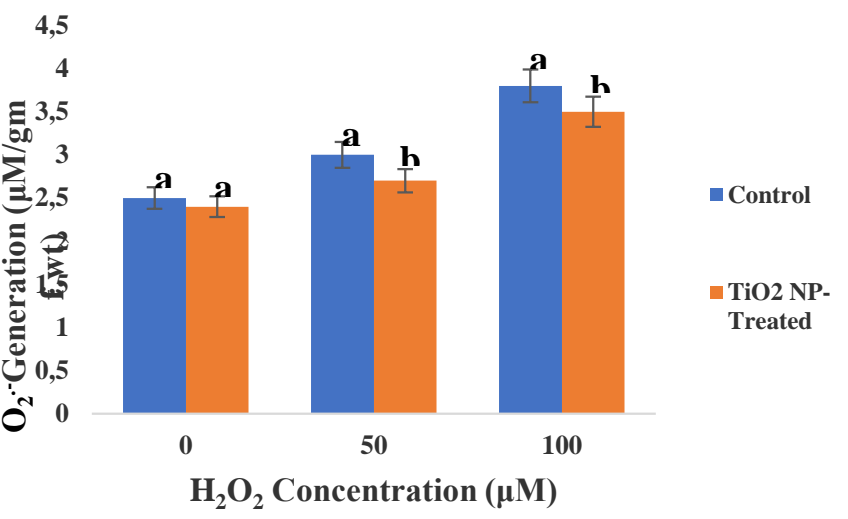

Figure 1 Determination of $\mathrm{O}_{2}^{--}$generation under $\mathrm{H}_{2} \mathrm{O}_{2}$ treatments $(0,50$ \& $100 \mu \mathrm{M})$ in control and $\mathrm{TiO}_{2}-\mathrm{NP}$ pre-treated maize plants for 3 days. Data represented as mean of three replicates $(n=3) \pm S E$ and $S E$ represented as vertical bar on each column. Different letters indicate significant differences through Duncan's t-test at $\mathrm{p} \leq 0.05$. riboflavin the reaction was initiated under continuous illumination of two $10 \mathrm{~W}$ fluorescent lamp for $30 \mathrm{~min}$. A blank set was run where illumination was withdrawn. The absorbance of the illuminated set was read at $560 \mathrm{~nm}$ and activity was calculated with the inhibition of formazan formation through NBT reduction as suggested by Giannopolitis \& Ries (1977); Cakmak \& Marschner (1992).

\section{Glutathione reductase (GR: EC 1.6.4.2)}

The in-vitro activity of GR was done as suggested by Cakmak $\boldsymbol{\&}$ Marschner (1992). For the enzyme activity, partially purified enzyme extract was reacted in an assay mixture containing $50 \mathrm{mM}$ Tris- $\mathrm{HCl}(\mathrm{pH} 7.5), 0.15 \mathrm{mM} \mathrm{NAD}(\mathrm{P}) \mathrm{H}, 1 \mathrm{mM}$ GSSG, $3 \mathrm{mM} \mathrm{MgCl} 2$ and $100 \mu \mathrm{g}$ equivalent partially purified protein extract. The changes of $\mathrm{NAD}(\mathrm{P}) \mathrm{H}$ oxidation with the decrease in absorbance at $340 \mathrm{~nm}$ was recorded. Activity was expressed as $\mu \mathrm{M} \mathrm{NAD}(\mathrm{P}) \mathrm{H}$ oxidized $/ \mathrm{min} / \mathrm{mg}$ protein using $6.22 \mathrm{mM}^{-1} \mathrm{~cm}^{-1}$ as extinction co-efficient of $\mathrm{NAD}(\mathrm{P}) \mathrm{H}$. Protein of the partially purified enzyme extract was determined with Bradford reagent (Bradford, 1976)

\section{Catalase (CAT: EC 1.11.1.6)}

The catalase was assayed in an extraction buffer as suggested by Verma \& Dubey (2003). With $100 \mu \mathrm{g}$ equivalent protein from partially purified protein extract was reacted in $200 \mathrm{mM}$ phosphate buffer $(\mathrm{pH} 7.0)$ and $100 \mathrm{mM} \mathrm{H}_{2} \mathrm{O}_{2}$. The incubated mixture at $25^{\circ} \mathrm{C}$ was immediately recorded for decreasing absorbance at $240 \mathrm{~nm}$. The activity of catalase was expressed as $\mu \mathrm{M} \mathrm{H}_{2} \mathrm{O}_{2}$ oxidized $/ \mathrm{min} / \mathrm{mg}$ protein using the molar extinction co-efficient of $39.4 \mathrm{M}^{-1} \mathrm{~cm}^{-1}$ for $\mathrm{H}_{2} \mathrm{O}_{2}$.

\section{Statistical analysis}

Recorded data were statistically analyzed with one-way ANOVA using the general linear model. The variations between the means of treatments for three replications were compared with t-tests $(\mathrm{P} \leq 0.05)$.

\section{RESULTS}

Initially plants recorded hardly any significant morphological variations among the treatments. However, the oxidative stress imposed by varied concentration of $\mathrm{H}_{2} \mathrm{O}_{2}$ recorded with significant variation of the maize plants on cellular activities. Still, pre-treatment with $\mathrm{TiO}_{2}-\mathrm{NP}$ satisfied for some responses on any moderation of oxidative stress in maize plants.

\section{Changes of ROS under treatments}

Both $\mathrm{O}_{2}^{--}$and $\mathrm{H}_{2} \mathrm{O}_{2}$ was consider to evaluate for the changes of ROS of control and pre-treated maize cultivar. It is clear from the observation that $\mathrm{O}_{2}{ }^{-}$ accumulation was dose dependent of $\mathrm{H}_{2} \mathrm{O}_{2}$ treatment. The ranges were 1.20 \& 1.52-fold in control plants and $1.12 \& 1.45$-fold in $\mathrm{TiO}_{2}-\mathrm{NP}$ pre-treated plants under 50 and $100 \mu \mathrm{M} \mathrm{H}_{2} \mathrm{O}_{2}$ treatment as compared to $0 \mu \mathrm{M} \mathrm{H}_{2} \mathrm{O}_{2}$. Likewise, the application of $\mathrm{TiO}_{2}-\mathrm{NP}$ through pre-treatment was significantly in moderation of $\mathrm{O}_{2}{ }^{-}$generation. Thus, the minimum value was recorded by 10.00 and $7.89 \%$ under 50 and $100 \mu \mathrm{M} \mathrm{H}_{2} \mathrm{O}_{2}$ treatment as compared to control (without treatments) plants (Figure 1). In a similar manner, accumulation of $\mathrm{H}_{2} \mathrm{O}_{2}$ had the compatible trend through the $\mathrm{H}_{2} \mathrm{O}_{2}$ treatments in plants. The maximum accumulation was recorded under 50 and $100 \mu \mathrm{M}$ of $\mathrm{H}_{2} \mathrm{O}_{2}$ treatment by $1.17 \& 1.31$-fold in control and 1.05 \& 1.16-fold in $\mathrm{TiO}_{2}-\mathrm{NP}$ pre-treated plants. Interesting to note that, $\mathrm{TiO}_{2}-\mathrm{NP}$ pretreatment on the $0 \mu \mathrm{M} \mathrm{H}_{2} \mathrm{O}_{2}$ concentration had not any significant changes of $\mathrm{H}_{2} \mathrm{O}_{2}$ accumulation, whereas, plants were relieved by 7.31 and $8.69 \%$ with $\mathrm{TiO}_{2}$ NP pre-treatment under respective higher oxidative exposure (Figure 2).

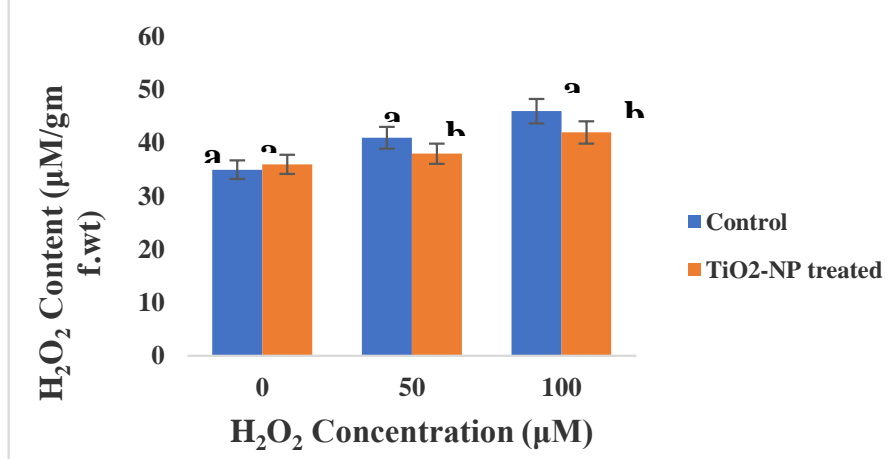

Figure 2 Determination of $\mathrm{H}_{2} \mathrm{O}_{2}$ content under $\mathrm{H}_{2} \mathrm{O}_{2}$ treatments $(0,50 \& 100 \mu \mathrm{M})$ in control and $\mathrm{TiO}_{2}-\mathrm{NP}$ pre-treated maize plants for 3 days. Data represented as mean of three replicates $(n=3) \pm$ SE and SE represented as vertical bar on each column. Different letters indicate significant differences through Duncan's t-test at $\mathrm{p} \leq 0.05$.

\section{Tissue specific distribution of $\mathrm{H}_{2} \mathrm{O}_{2}$ and $\mathrm{O}_{2}{ }^{-}$}

Figure 3C \& D shows a distinct demarcation on leaf tissue specific in-vivo detection by NBT staining for ROS with regards to $\mathrm{O}_{2}{ }^{-}$. This is clear from the accumulation of ROS and its complex with tetrazolium through un-uniform patches more toward leaf base and margin. The impact of $\mathrm{H}_{2} \mathrm{O}_{2}$ is concomitant with the $\mathrm{O}_{2}^{--}$accumulation being the maximum patches on $100 \mu \mathrm{M} \mathrm{H} \mathrm{H}_{2} \mathrm{O}_{2}$ concentration. Interesting to note that $\mathrm{TiO}_{2}-\mathrm{NP}$ observed a significant moderation for $\mathrm{O}_{2}{ }^{--}$accumulation through in-vivo detection. In comparison to untreated or control, the accumulation of $\mathrm{O}_{2}^{-{ }^{-}}$recorded more less under $\mathrm{TiO}_{2}-\mathrm{NP}$ pretreatment. Another ROS, $\mathrm{H}_{2} \mathrm{O}_{2}$ was also more differentially accumulated under control and $\mathrm{TiO}_{2}-\mathrm{NP}$ pre-treatment by. From figure $3 \mathrm{~A} \& \mathrm{~B}$, it is quite evident that $\mathrm{H}_{2} \mathrm{O}_{2}$ exposure could also induce in-vivo accumulation of $\mathrm{H}_{2} \mathrm{O}_{2}$ by DAB staining, however, through concentration gradient. Still, on pre-treatment set regardless of $\mathrm{H}_{2} \mathrm{O}_{2}$ concentration $\mathrm{TiO}_{2}-\mathrm{NP}$ undoubtedly registered its quite significant effect by down regulation of ROS accumulation.

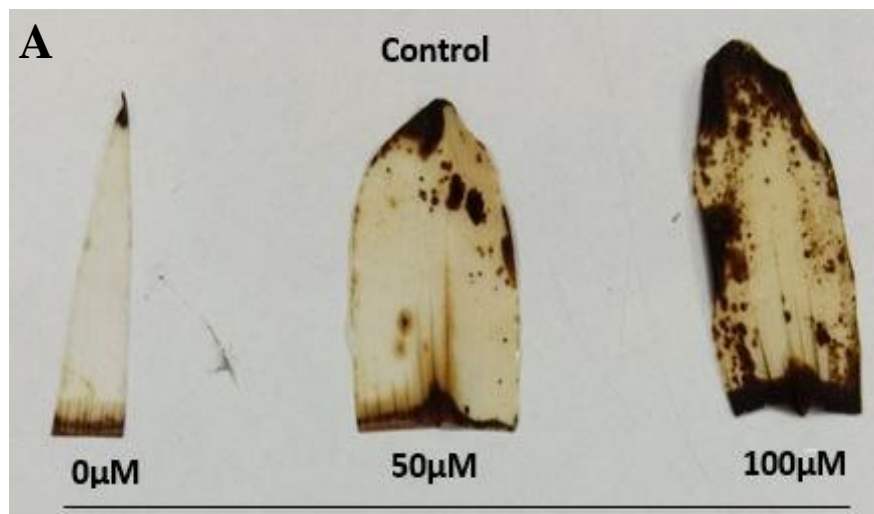

$\mathrm{H}_{2} \mathrm{O}_{2}$ treatment 


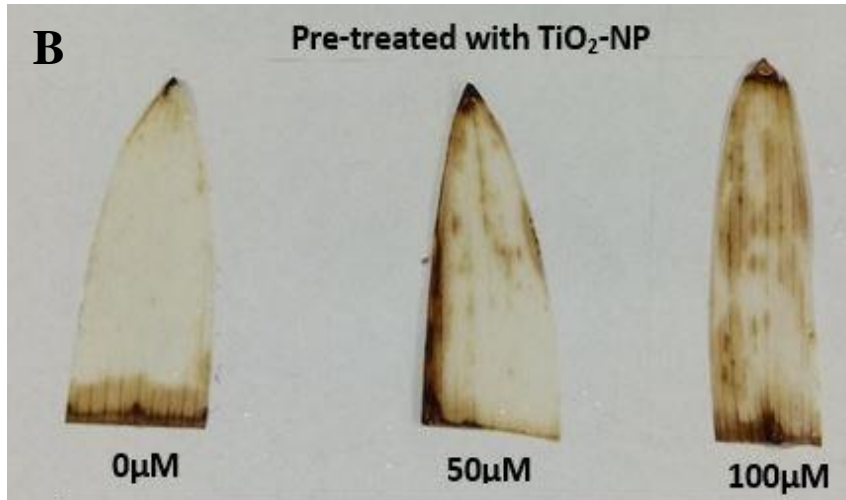

$\mathrm{H}_{2} \mathrm{O}_{2}$ treatment

C

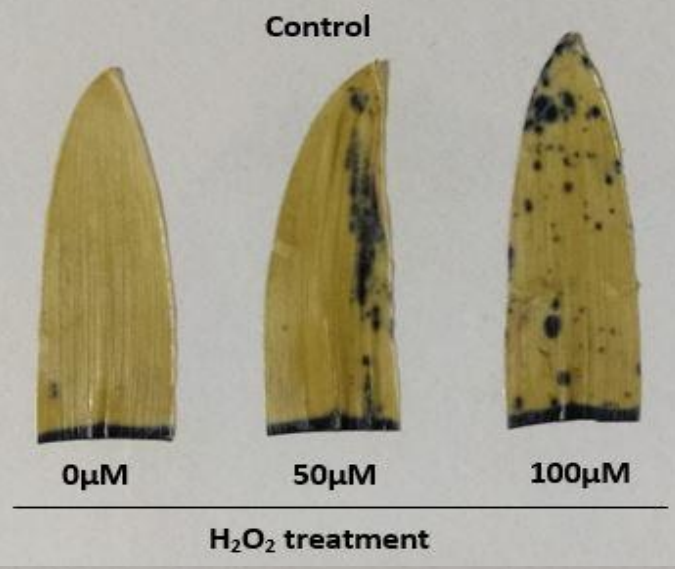

D

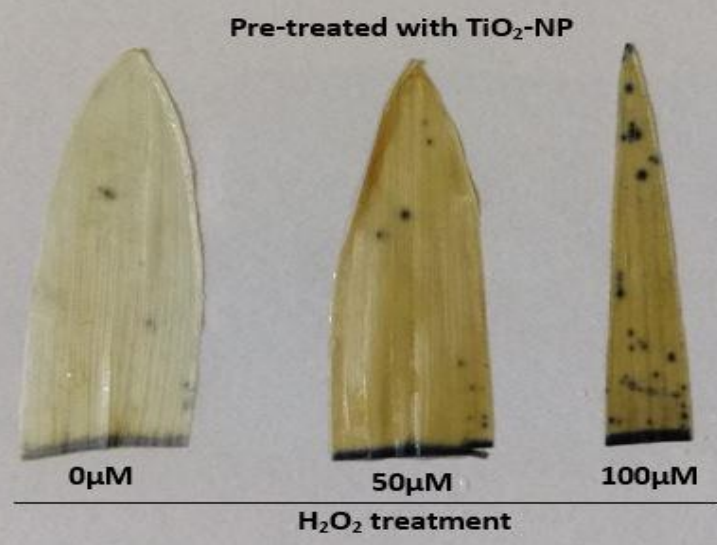

Figure 3 Histochemical detection of $\mathrm{H}_{2} \mathrm{O}_{2}$ by DAB staining (A and $\mathrm{B}$ ) and $\mathrm{O}_{2}$ by NBT staining $(\mathrm{C}$ and $\mathrm{D})$ under $0,50,100 \mu \mathrm{M} \mathrm{H}_{2} \mathrm{O}_{2}$ treatment in control (A \& C) and pre-treated $\mathrm{TiO}_{2}-\mathrm{NP}(\mathrm{B} \& \mathrm{D})$ maize plants in leaf.

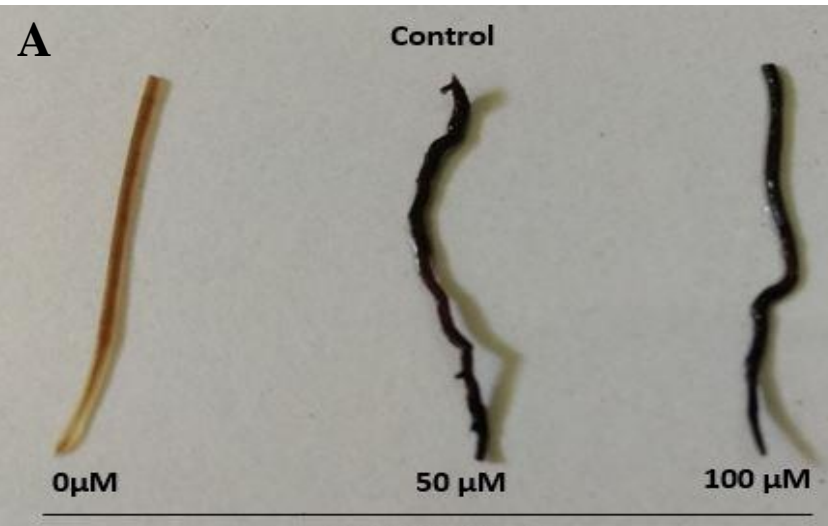

$\mathrm{H}_{2} \mathrm{O}_{2}$ treatment

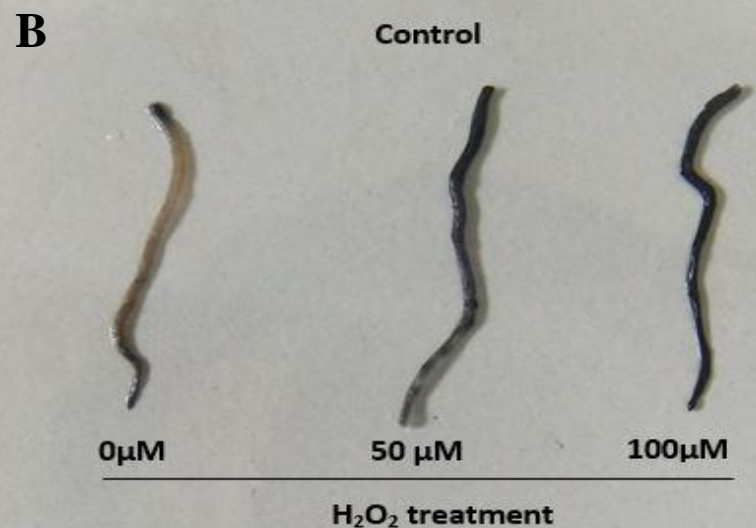

Roots being the most vulnerable tissue received the impact of oxidative stress were recorded by NBT staining. In comparison to leaf, roots recorded more intense colouration in gradient $0-100 \mu \mathrm{M} \mathrm{H}_{2} \mathrm{O}_{2}$ concentration under control which under gone more revised with $\mathrm{TiO}_{2}-\mathrm{NP}$ pre-treated plants (Figure $4 \mathrm{C} \& \mathrm{D}$ ). It is clearly shown that impact of nanoparticle is more pronounced in higher concentration of $\mathrm{H}_{2} \mathrm{O}_{2}$. The DAB staining of $\mathrm{H}_{2} \mathrm{O}_{2}$ accumulation had some differential expression where $\mathrm{TiO}_{2}-\mathrm{NP}$ appeared as most retrieving at $100 \mu \mathrm{M}$ $\mathrm{H}_{2} \mathrm{O}_{2}$ (Figure 4A \& B). Still, at lower concentration plants were retrieved to reduce the $\mathrm{H}_{2} \mathrm{O}_{2}$ by $\mathrm{TiO}_{2}-\mathrm{NP}$. Therefore, $\mathrm{TiO}_{2}-\mathrm{NP}$ and $\mathrm{H}_{2} \mathrm{O}_{2}$ is more discriminating in reaction according to external concentration of $\mathrm{H}_{2} \mathrm{O}_{2}$.
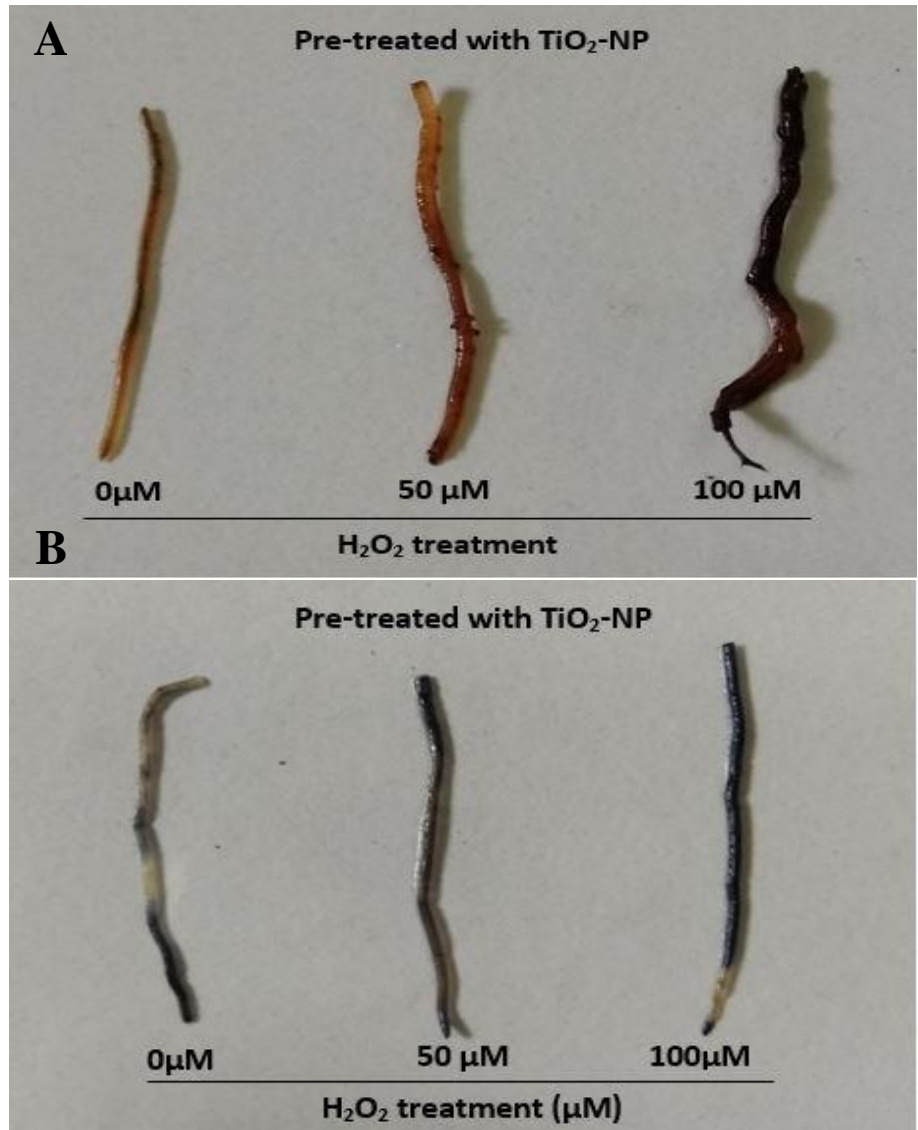

Figure 4 Histochemical detection of $\mathrm{H}_{2} \mathrm{O}_{2}$ by DAB staining (A and $\mathrm{B}$ ) and $\mathrm{O}_{2}$ by NBT staining $(\mathrm{C}$ and $\mathrm{D})$ under $0,50,100 \mu \mathrm{M} \mathrm{H}_{2} \mathrm{O}_{2}$ treatment in control (A \& C) and pre-treated $\mathrm{TiO}_{2}-\mathrm{NP}(\mathrm{B} \& \mathrm{D})$ maize plants in roots.

\section{Generation of MDA and carbonyl content}

On account of ROS induced oxidative damages, plants recorded a significant variation with regards to lipid peroxidation and protein oxidation. A quantification of lipid peroxide as MDA has synergistic trend according to control and $\mathrm{TiO}_{2}-\mathrm{NP}$ pre-treatment was recorded. Thus, the peak accumulation of MDA at maximum $\mathrm{H}_{2} \mathrm{O}_{2}$ concentration was 1.23-fold as compared to $0 \mu \mathrm{M} \mathrm{H}_{2} \mathrm{O}_{2}$ concentration in control plants. This was quite significant for the effect of pretreatment with $\mathrm{TiO}_{2}-\mathrm{NP}$ that show a moderation with $7.45 \& 7.06 \%$ depletion at 50 and $100 \mu \mathrm{M} \mathrm{H}_{2} \mathrm{O}_{2}$ concentration respectively and also $5.24 \%$ decline recorded even in $0 \mu \mathrm{M} \mathrm{H}_{2} \mathrm{O}_{2}$ concentration (Figure 5). However, MDA content increases through $\mathrm{H}_{2} \mathrm{O}_{2}$ concentrations in both control and pre-treated plants. This was 
quite inconsistent level of protein and its epoxide product as carbonyl content had an almost compatible trend. The moderation of carbonyl content of protein oxidation with $\mathrm{TiO}_{2}-\mathrm{NP}$ pre-treatment was maximum at 50 \& $100 \mu \mathrm{M} \mathrm{H}_{2} \mathrm{O}_{2}$ concentration by lowering the value 5.91 and $5.74 \%$ as compared to control plants (Figure 6). But, at $0 \mu \mathrm{M} \mathrm{H}_{2} \mathrm{O}_{2}$ concentration $\mathrm{TiO}_{2}-\mathrm{NP}$ had not any impacts Therefore, $\mathrm{TiO}_{2}-\mathrm{NP}$ behaved as a reliever only when it encountered the oxidative stress mediated by varying concentration of $\mathrm{H}_{2} \mathrm{O}_{2}$.

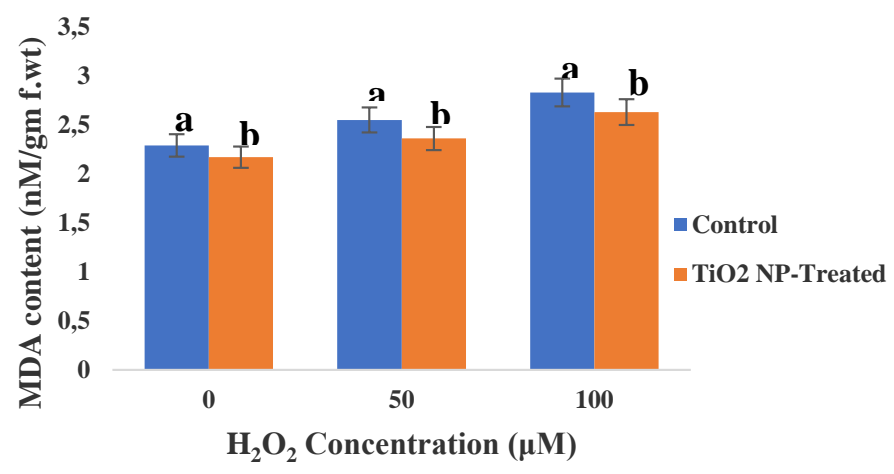

Figure 5 Determination of MDA content under $\mathrm{H}_{2} \mathrm{O}_{2}$ treatments $(0,50$ \& $100 \mu \mathrm{M})$ in control and $\mathrm{TiO}_{2}$-NP pre-treated maize plants for 3 days. Data represented as mean of three replicates $(n=3) \pm S E$ and SE represented as vertical bar on each column. Different letters indicate significant differences through Duncan's t-test at $\mathrm{p} \leq 0.05$.

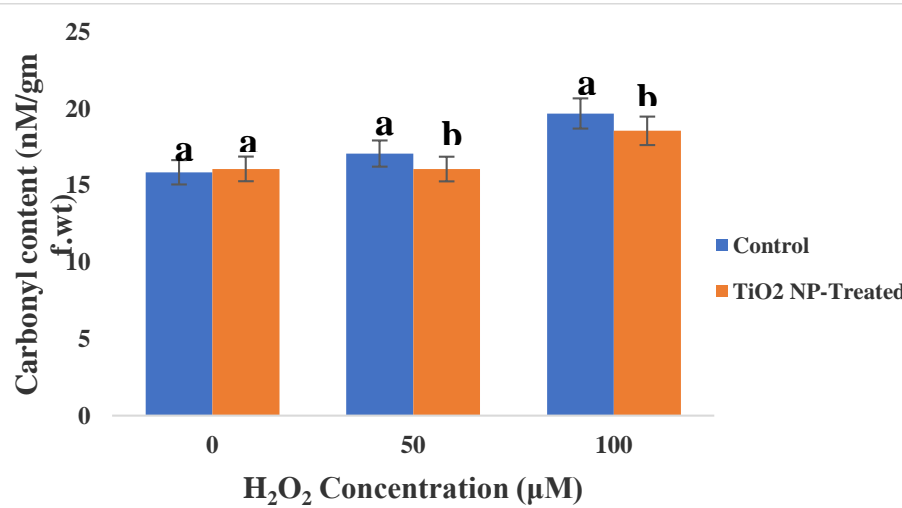

Figure 6 Determination of carbonyl content under $\mathrm{H}_{2} \mathrm{O}_{2}$ treatments $(0,50$ \& $100 \mu \mathrm{M})$ in control and $\mathrm{TiO}_{2}-\mathrm{NP}$ pre-treated maize plants for 3 days. Data represented as mean of three replicates $(n=3) \pm S E$ and SE represented as vertical bar on each column. Different letters indicate significant differences through Duncan's t-test at $\mathrm{p} \leq 0.05$.

\section{Changes in proline content}

In the present experiment, the sensitivity of plants to $\mathrm{H}_{2} \mathrm{O}_{2}$ was also recorded otherwise through compatible solute accumulation. The activity of proline was granted as compatible solutes developed in the tissues as the plant progressed through $50,100 \mu \mathrm{M} \mathrm{H}_{2} \mathrm{O}_{2}$ concentration. Under control condition they are recorded a subdued accumulation of proline in a range of $11.6 \& 26.6 \%$ (Figure 7). $\mathrm{TiO}_{2}-\mathrm{NP}$ as pre-treatment was quite interesting to relieve the water stress as mediated by $\mathrm{H}_{2} \mathrm{O}_{2}$ through up-regulated values. Notably, the trend of proline accumulation under $\mathrm{TiO}_{2}$-NP pre-treatment was in downhill order, however, significantly $(\mathrm{P} \leq 0.05)$ higher against control plants for each $\mathrm{H}_{2} \mathrm{O}_{2}$ concentration as exogenous exposure. Thus, the values recorded to retrieve the proline content by 1.17 -fold \& 1.23-fold (Figure 7) under $50 \& 100 \mu \mathrm{M} \mathrm{H}_{2} \mathrm{O}_{2}$ concentration established a good source of proline induction.

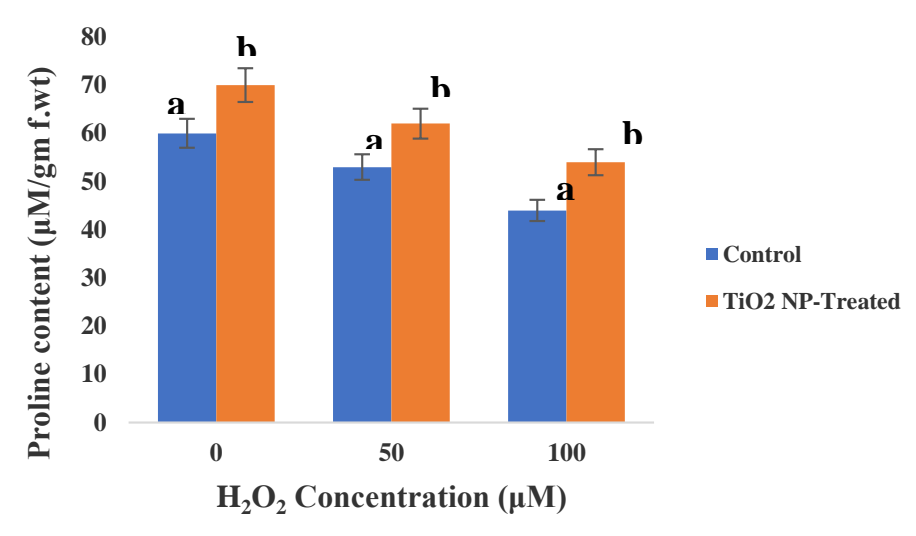

Figure 7 Determination of proline content under $\mathrm{H}_{2} \mathrm{O}_{2}$ treatments $(0,50$ \& $100 \mu \mathrm{M})$ in control and $\mathrm{TiO}_{2}-\mathrm{NP}$ pre-treated maize plants for 3 days. Data represented as mean of three replicates $(n=3) \pm S E$ and SE represented as vertical bar on each column. Different letters indicate significant differences through Duncan's t-test at $\mathrm{p} \leq 0.05$

\section{Changes in NADP-ME activity}

In an attempt to analyse the photosynthetic mode of plant's response through $\mathrm{H}_{2} \mathrm{O}_{2}$ toxicity NADP-ME activity was assayed. Interesting to note that, this $\mathrm{C}_{4}$ enzyme, basically an oxidative decarboxylase has its discriminatory trend as a function of $\mathrm{H}_{2} \mathrm{O}_{2}$ concentration as compared to $0 \mu \mathrm{M} \mathrm{H}_{2} \mathrm{O}_{2}$ concentration. The activity got significantly subdued under $50 \mu \mathrm{M} \mathrm{H}_{2} \mathrm{O}_{2}$ treatment. This again retrieved the activity by $1.25 \& 1.22$-fold in control and $\mathrm{TiO}_{2}-\mathrm{NP}$ pre-treated plants under highest concentration of $\mathrm{H}_{2} \mathrm{O}_{2}$, i.e. $100 \mu \mathrm{M}$ (Figure 8). The activity of $\mathrm{TiO}_{2}$-NP pre-treated plants had the concomitant response following the $\mathrm{H}_{2} \mathrm{O}_{2}$ doses. Therefore, the $\mathrm{TiO}_{2}-\mathrm{NP}$ as pre-treatment appeared to retrieve the decarboxylase activity with a complex manner with interaction of $\mathrm{H}_{2} \mathrm{O}_{2}$. The inducing activity of $\mathrm{TiO}_{2}-\mathrm{NP}$ was evident both under 50 \& $100 \mu \mathrm{M} \mathrm{H} \mathrm{H}_{2} \mathrm{O}_{2}$ concentration which recorded $1.23 \& 1.20$-fold over expression as compare to control plants respectively.

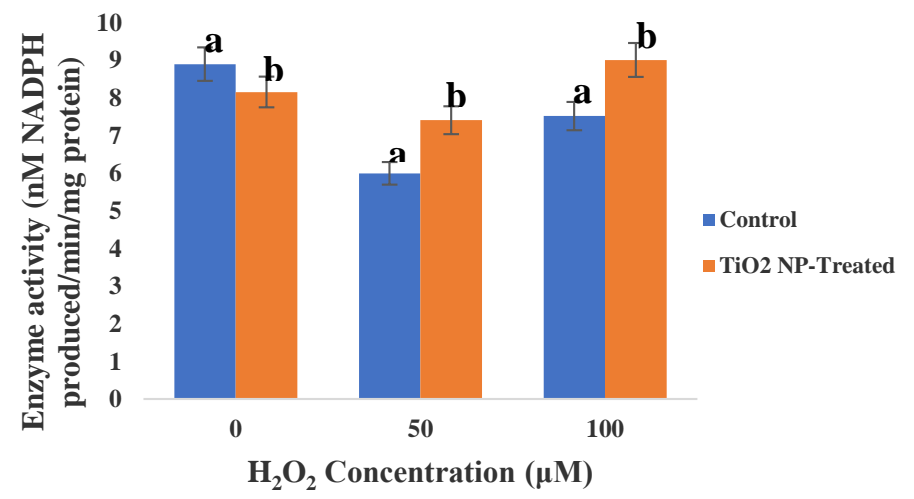

Figure 8 Assay of NADP-ME activity under $\mathrm{H}_{2} \mathrm{O}_{2}$ treatments $(0,50 \& 100 \mu \mathrm{M})$ in control and $\mathrm{TiO}_{2}-\mathrm{NP}$ pre-treated maize plants for 3 days. Data represented as mean of three replicates $(n=3) \pm$ SE and SE represented as vertical bar on each column. Different letters indicate significant differences through Duncan's t-test at $\mathrm{p} \leq 0.05$.

\section{Changes in anti-oxidant enzymes activities}

The activities of peroxidase when consider taking guaiacol as electron donor, it recorded an inconsistent manner as a function of $\mathrm{H}_{2} \mathrm{O}_{2}$ concentration. Thus, even under $0 \mu \mathrm{M} \mathrm{H}_{2} \mathrm{O}_{2}$ concentration $\mathrm{TiO}_{2}-\mathrm{NP}$ recorded as most inducing to raise the activity at the peak by 1.07 -fold. This trend was maintained in compatible manner by 1.069 -fold increase for $50 \mu \mathrm{M} \mathrm{H}_{2} \mathrm{O}_{2}$ treatment over control plants. But the activity of enzyme subdued by $20.04 \& 20.14 \%$ for control and $\mathrm{TiO}_{2}-\mathrm{NP}$ pretreated plants respectively at $50 \mu \mathrm{M} \mathrm{H}_{2} \mathrm{O}_{2}$ concentration over the $0 \mu \mathrm{M} \mathrm{H} \mathrm{H}_{2} \mathrm{O}_{2}$ concentration. However, the activity has significantly recovered with the induction of $100 \mu \mathrm{M} \mathrm{H}_{2} \mathrm{O}_{2}$ by $1.23 \& 1.11$-fold increase in control and $\mathrm{TiO}_{2}-\mathrm{NP}$ pre-treated plants respectively as compare to $50 \mu \mathrm{M} \mathrm{H}_{2} \mathrm{O}_{2}$ concentration (Figure 9). 


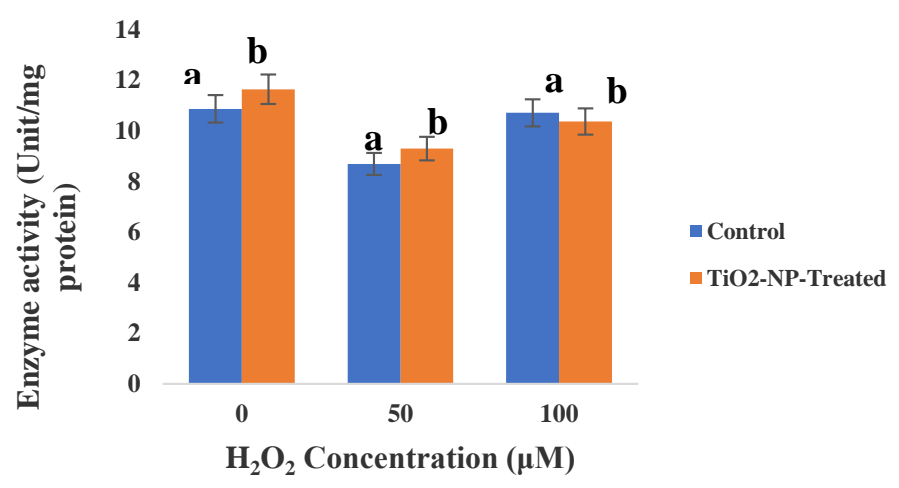

Figure 9 Assay of GPX activity under $\mathrm{H}_{2} \mathrm{O}_{2}$ treatments $(0,50 \& 100 \mu \mathrm{M})$ in control and $\mathrm{TiO}_{2}$-NP pre-treated maize plants for 3 days. Data represented as mean of three replicates $(n=3) \pm \mathrm{SE}$ and $\mathrm{SE}$ represented as vertical bar on each column. Different letters indicate significant differences through Duncan's t-test at $\mathrm{p} \leq 0.05$.

From the zymographic studies with GPX as revealed by $o$-dianisidine reactions, the variations for polypeptides were quite significant (Figure 10). As a function of $\mathrm{H}_{2} \mathrm{O}_{2}$ concentration, maize plants recorded maximum over expression at $0 \mu \mathrm{M}$ $\mathrm{H}_{2} \mathrm{O}_{2}$ regardless of control and $\mathrm{TiO}_{2}-\mathrm{NP}$ pre-treatment. Though there are no variations in number, however, their intensities varied all through the treatments This was more clarified with densitometric analysis for individual polypeptides as represented in Figure 11. Interestingly, this trend of $\mathrm{TiO}_{2}-\mathrm{NP}$ induced over expression was carried forward through $\mathrm{H}_{2} \mathrm{O}_{2}$ stress more towards lower concentration.

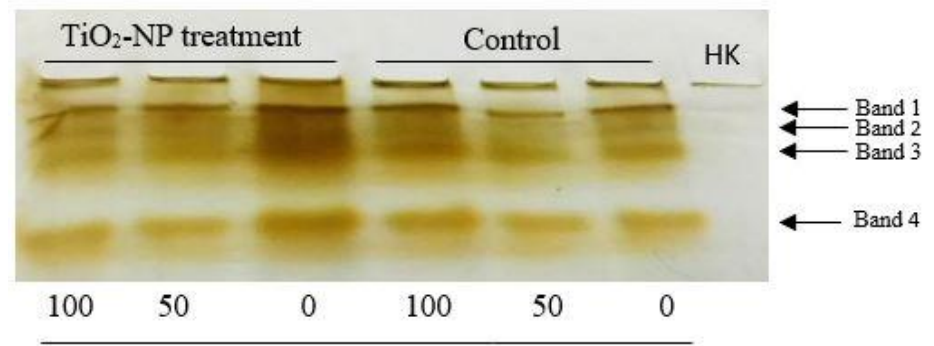

$\mathrm{H}_{2} \mathrm{O}_{2}$ treatment $(\mu \mathrm{M})$

Figure 10 Resolving of polymorphism of peroxidase (GPX) through various $\mathrm{H}_{2} \mathrm{O}_{2}$ treatments $(0,50,100 \mu \mathrm{M})$ when interacted with $\mathrm{TiO}_{2}-\mathrm{NP}$. ' $\mathrm{HK}$ ' denotes Heat killed enzyme protein.

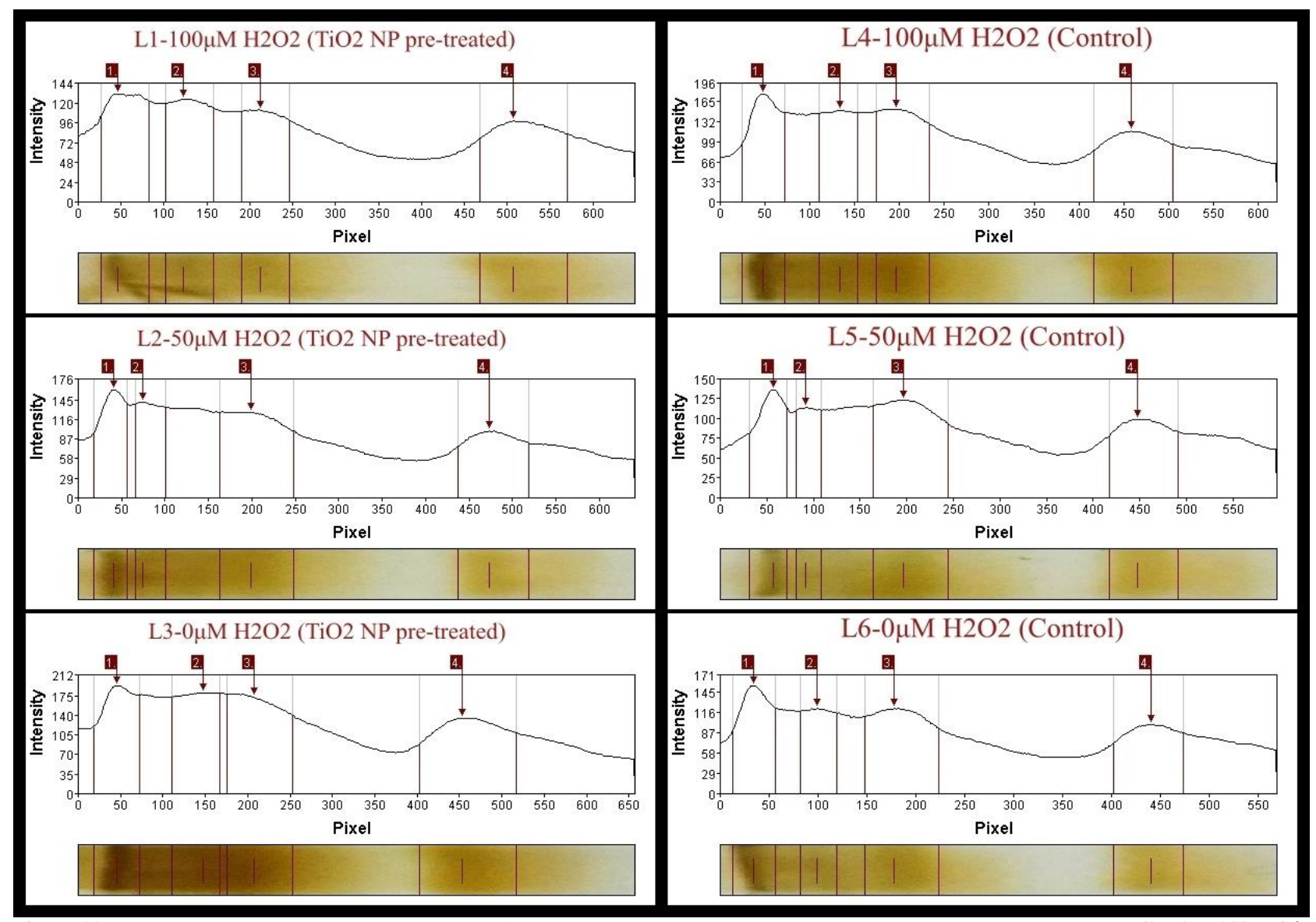

Figure 11 Densitometric analysis for intensity profiles of GPX on different polymorphic bands under varying treatments of $\mathrm{H}_{2} \mathrm{O}_{2}(0,50 \& 100 \mu \mathrm{M})$ in control and $\mathrm{TiO}_{2}-\mathrm{NP}$ pre-treated plants. L1, L2, L3, L4, L5 \& L6 denotes the different lanes on native gel run with partially purified protein

In continuation with peroxidase reaction, the maize plants have also shown their potential to minimize the $\mathrm{O}_{2}{ }^{-}$content by SOD activity. Interesting to note that in control plants the variations of $\mathrm{H}_{2} \mathrm{O}_{2}$ concentration was not significantly demarked the SOD activity. Still, $\mathrm{TiO}_{2}-\mathrm{NP}$ becomes an inducer to over-express the SOD activities in a linear order by $1.27,1.36 \& 1.42$-fold through $\mathrm{H}_{2} \mathrm{O}_{2}$ concentrations (Figure 12). Thus, in comparison to $0 \mu \mathrm{M} \mathrm{H}_{2} \mathrm{O}_{2}$ concentration the variations in enzyme activities under $\mathrm{TiO}_{2}-\mathrm{NP}$ pre-treatment were 1.18 and 1.15fold through $\mathrm{H}_{2} \mathrm{O}_{2}$ concentrations. 


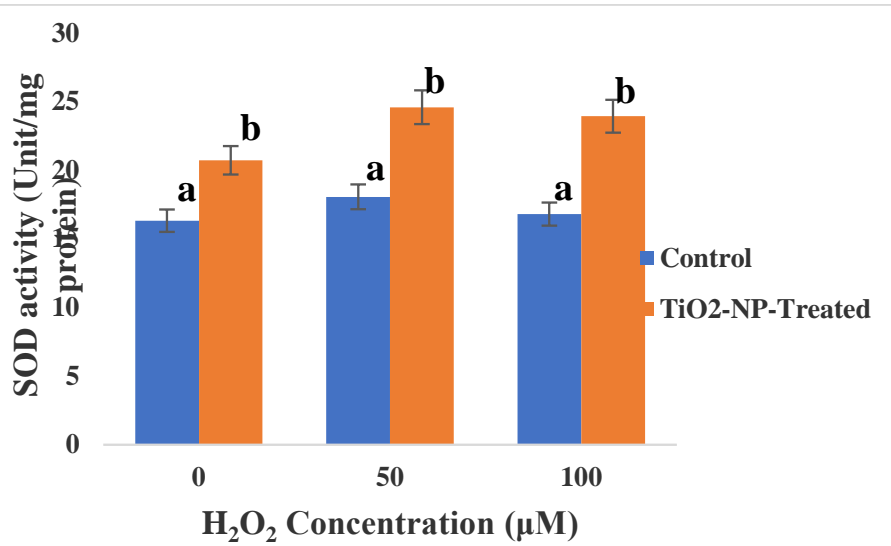

Figure 12 Assay of SOD activity under $\mathrm{H}_{2} \mathrm{O}_{2}$ treatments $(0,50 \& 100 \mu \mathrm{M})$ in control and $\mathrm{TiO}_{2}-\mathrm{NP}$ pre-treated maize plants for 3 days. Data represented as mean of three replicates $(n=3) \pm S E$ and SE represented as vertical bar on each column. Different letters indicate significant differences through Duncan's t-test at $\mathrm{p} \leq 0.05$

In response to depleted redox through $\mathrm{H}_{2} \mathrm{O}_{2}$ concentrations the maize plants recorded a significant $(\mathrm{P} \leq 0.05)$ as well as discriminating variations in glutathione metabolism in the present experiment. Interesting to note that $\mathrm{TiO}_{2}-\mathrm{NP}$ was in command to induce the GR activity over control plants but in downhill order through $\mathrm{H}_{2} \mathrm{O}_{2}$ concentrations (Figure 13). A record of 1.30-fold increase of GR activity with $\mathrm{TiO}_{2}$-NP pre-treatment even under $0 \mu \mathrm{M} \mathrm{H}_{2} \mathrm{O}_{2}$ concentration was found. It is also interesting to note that the changes in GR activities through 50 and $100 \mu \mathrm{M} \mathrm{H}_{2} \mathrm{O}_{2}$ concentrations were discriminatory between control and $\mathrm{TiO}_{2}$ $\mathrm{NP}$ pre-treatment. However, $\mathrm{H}_{2} \mathrm{O}_{2}$ and $\mathrm{TiO}_{2}-\mathrm{NP}$ interactions had the maximum value with 1.42-fold increase under $50 \mu \mathrm{M} \mathrm{H}_{2} \mathrm{O}_{2}$ concentration. This got reversed at $100 \mu \mathrm{M} \mathrm{H}_{2} \mathrm{O}_{2}$ concentration where $\mathrm{TiO}_{2}-\mathrm{NP}$ had suppressed the by $13.4 \%$ over $0 \mu \mathrm{M} \mathrm{H}_{2} \mathrm{O}_{2}$ concentration.

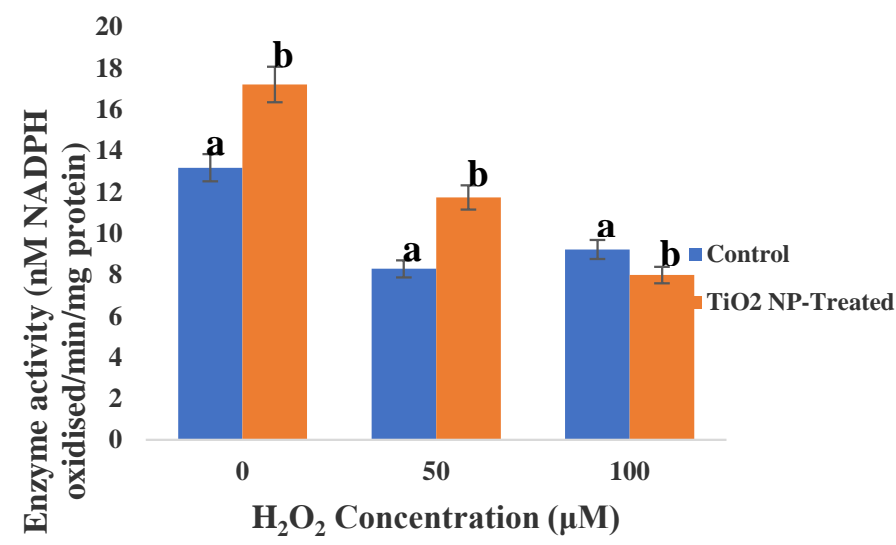

Figure 13 Assay of GR activity under $\mathrm{H}_{2} \mathrm{O}_{2}$ treatments $(0,50 \& 100 \mu \mathrm{M})$ in control and $\mathrm{TiO}_{2}-\mathrm{NP}$ pre-treated maize plants for 3 days. Data represented as mean of three replicates $(n=3) \pm S E$ and SE represented as vertical bar on each column. Different letters indicate significant differences through Duncan's t-test at $\mathrm{p} \leq 0.05$

In accompanying with anti-oxidative enzymes, CAT is the one which doesn't require any phenolic residues as electron donor to reduce the ROS. Therefore, in present case $\mathrm{TiO}_{2}-\mathrm{NP}$ pre-treated plants are found with discriminating trends in activities passing through varying concentration of $\mathrm{H}_{2} \mathrm{O}_{2}$. Notably, the plant recorded the maximum CAT activity under $0 \mu \mathrm{M} \mathrm{H}_{2} \mathrm{O}_{2}$ dose, more with $\mathrm{TiO}_{2}-\mathrm{NP}$ treated plants by 1.17 -fold over expression over control plants. Thereafter, a significant downhill activity through 50 and $100 \mu \mathrm{M} \mathrm{H}_{2} \mathrm{O}_{2}$ concentration were recorded by $33 \& 53 \%$ and $37 \& 57 \%$ in control and $\mathrm{TiO}_{2}-\mathrm{NP}$ pre-treated plants respectively as compared to $0 \mu \mathrm{M} \mathrm{H}_{2} \mathrm{O}_{2}$ concentration (Figure 14). However, a intermediate $\mathrm{H}_{2} \mathrm{O}_{2}$ concentration $(50 \mu \mathrm{M})$ both control and $\mathrm{TiO}_{2}-\mathrm{NP}$ treatment were significantly varied showing 1.10 -fold expression under nanoparticle treatment. Unexpectedly at maximum $\mathrm{H}_{2} \mathrm{O}_{2}$ concentration had no such significant $(\mathrm{P} \leq 0.05)$ variation between control and $\mathrm{TiO}_{2}-\mathrm{NP}$ pre-treated plants.

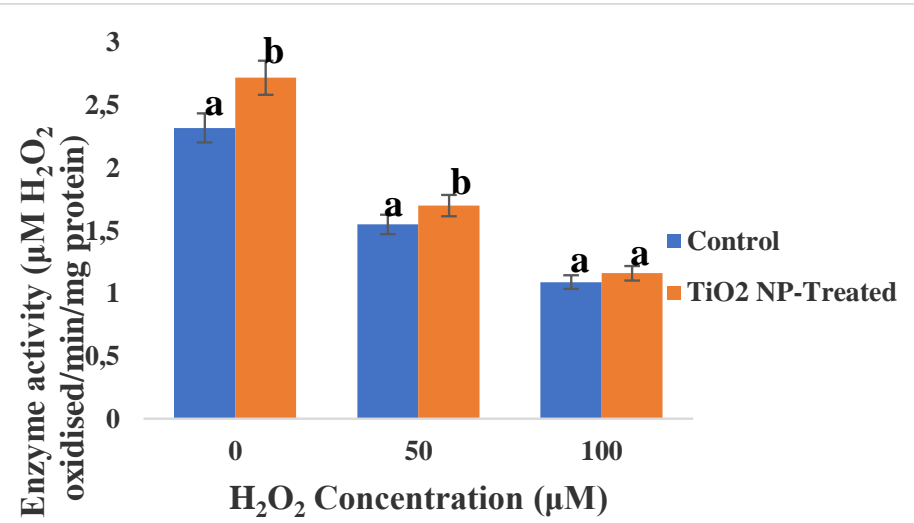

Figure 14 Assay of CAT activity under $\mathrm{H}_{2} \mathrm{O}_{2}$ treatments $(0,50 \& 100 \mu \mathrm{M})$ in control and $\mathrm{TiO}_{2}-\mathrm{NP}$ pre-treated maize plants for 3 days. Data represented as mean of three replicates $(n=3) \pm S E$ and SE represented as vertical bar on each column. Different letters indicate significant differences through Duncan's t-test at $\mathrm{p} \leq 0.05$

\section{DISCUSSION}

The impacts of nano particle mediated plant responses are complex as well as inconsistent in nature for genotypes and types of nano materials. Oxidative burst is common consequence for induced ROS accumulation in plant tissues. $\mathrm{H}_{2} \mathrm{O}_{2}$ has already been implicated with dual functions: as ROS itself and an inducer of biochemical paths as secondary messenger (Petrov \& Van Breusegem, 2012) Therefore, $\mathrm{TiO}_{2}-\mathrm{NP}$ would be interesting to note the variations in ROS under the influence of oxidative exposure in maize. On initial observation, maize plants appeared to be more sensitive to accumulate a significant amount of $\mathrm{H}_{2} \mathrm{O}_{2}$ and $\mathrm{O}_{2}{ }^{--}$over $0 \mu \mathrm{M} \mathrm{H}_{2} \mathrm{O}_{2}$ dose. On the same time $\mathrm{TiO}_{2}-\mathrm{NP}$ had been able to register its impact in down-regulation of $\mathrm{ROS}$. $\mathrm{TiO}_{2}-\mathrm{NP}$ has already been referred with some inconsistent manner to the plant physiological responses. In the cereal crops this particle has its implication to induce the germination, seedling growth but not to any changes in apoplastic ROS (Goodarzi et al., 2017). However, in the present experiment $\mathrm{TiO}_{2}$-NP might be speculated with an effector to ROS mitigation. Gene activation either to induce the transcripts of secondary metabolites to scavenge the $\mathrm{H}_{2} \mathrm{O}_{2}$ or $\mathrm{TiO}_{2}-\mathrm{NP}$ itself to interact the apoplastic ROS would be the possibilities (Liu et al., 2017; Zahra et al., 2017). ROS being the primary inducer and inevitable fate of the molecular oxygen through it's over reduction is related to every kind of cellular process. With adequate osmotic potential, primarily, maize plants sustained the osmotic turgidity under $\mathrm{H}_{2} \mathrm{O}_{2}$ stress. This is evident from the down-regulation of proline in dose dependent manner. It is the fact that any abiotic factors influencing water stress may necessarily be linked with the changes of redox. In vis-a-vis a deficit of saturating moisture leve induces the over-reduction of electron transport chain generating ROS. Maize, an established $\mathrm{C}_{4}$ species is more tolerant to water stress and thereby, photooxidation and its down-stream effects of ROS generation thought to be related Therefore, plant cellular redox and osmotic homeostasis are complementary to each through the involvement of proline metabolism (Gupta et al., 2016). Thereby, $\mathrm{TiO}_{2}-\mathrm{NP}$ might have another role through maintenance of tissue hydration that undergoes perturbed with concentration of oxidizing agent, $\mathrm{H}_{2} \mathrm{O}_{2}$ as herein.

There is a clear-cut evidence about the interaction of $\mathrm{H}_{2} \mathrm{O}_{2}$ when in-vivo histochemical detection of $\mathrm{H}_{2} \mathrm{O}_{2}$ and $\mathrm{O}_{2}{ }^{--}$were recorded. This is more pronounced with the midrib portion for $\mathrm{O}_{2}{ }^{--}$accumulation by NBT staining within the tissues. This suggests initially the oxidative burst in development through the conducting tissues and its water stream movement by basipetally order. An excess amount of moisture deficit may initially be developed into tissue dehydration along the midribs (Lu \& Neumann, 1998). This might later be distributed through the mesophyll cells which are in-contiguous to xylem ducts and thus, a radical dispersion of the $\mathrm{O}_{2}^{--}$the results. This is quite in agreement that in the present study the distribution of $\mathrm{O}_{2}{ }^{--}$in the leaves is in order of marginal or central midrib traversing to the mesophyll tissues. However, the amelioration of $\mathrm{O}_{2}{ }^{--}$by $\mathrm{TiO}_{2}$ NP pre-treatment would either be justified to block the conversion of oxygen into $\mathrm{O}_{2}{ }^{--}$by single electron reduction (Karuppanapandian et al., 2011) or/and a consistent lysis by SOD activities. Still, later is well established with proportional activities of SOD as a function of $\mathrm{TiO}_{2}-\mathrm{NP}$ pre-treatment. Similar pattern was also recorded for DAB reaction mediated $\mathrm{H}_{2} \mathrm{O}_{2}$ accumulation in-vivo. In few citations it strengthens the activities of $\mathrm{H}_{2} \mathrm{O}_{2}$ lysing enzymes like peroxidase, catalase over-expressed with concomitant lysis for $\mathrm{H}_{2} \mathrm{O}_{2}$ (Zhao et al., 2012; Mandal et al., 2016). $\mathrm{TiO}_{2}-\mathrm{NP}$ mediated regulation of $\mathrm{H}_{2} \mathrm{O}_{2}$ production under consideration of oxidizing agents might not demand any accessory paths to check the generations of ROS. For the root segments $\mathrm{H}_{2} \mathrm{O}_{2}$ and $\mathrm{O}_{2}^{--}$appear to be most sensitive at the root tip region as it shown in the present experiment. Thus, the activity of $\mathrm{TiO}_{2}-\mathrm{NP}$ for nano-treatment is also likely to concentrate on those regions. $\mathrm{TiO}_{2}-\mathrm{NP}$ with its semi-conductor in nature has been more align with membrane potential of the root membrane. Thus, any changes regarding the 
electron transfer through respiratory chain and its over reduction to generate ROS is likely to be erased by $\mathrm{TiO}_{2}-\mathrm{NP}$. Moreover, for collaborative assessment of $\mathrm{O}_{2}$ and $\mathrm{H}_{2} \mathrm{O}_{2}$ lysis, SOD and GPX would be efficient instrumentals. The present investigation is more likely to accept this finding with earlier instances in maize treated with $\mathrm{TiO}_{2}-\mathrm{NP}$ under different abiotic stress (Yaqoob et al., 2018; Morteza et al., 2013)

As a consequence of oxidative stress as ensured by ROS $\left(\mathrm{O}_{2}{ }^{--}\right.$and $\left.\mathrm{H}_{2} \mathrm{O}_{2}\right)$ maize plants were synchronised with tolerance reactions to oxidative stress. Lipid peroxidation and protein oxidation are such those of ROS impacts where a sequential degradation of lipid residues are the features (Catala, 2009; Mano, 2012). In plant system, the development of lipid peroxides, hydroperoxides and carbonyl contents are produced in nucleophilic reactions by ROS on unsaturated residues of the membrane. In the present experiment, $\mathrm{TiO}_{2}-\mathrm{NP}$ was not appeared in a consistent manner but significant $(\mathrm{P} \leq 0.05)$ for moderation of ROS impacts Thus, for both lipid and protein oxidation, the $\mathrm{TiO}_{2}-\mathrm{NP}$ appeared as an ameliorator against $\mathrm{H}_{2} \mathrm{O}_{2}$ exposure. This obviously arises the possibilities for finer tuning but complex interaction of $\mathrm{TiO}_{2}-\mathrm{NP}$ with $\mathrm{H}_{2} \mathrm{O}_{2}$. Possibilities may exist either to down-regulate $\mathrm{H}_{2} \mathrm{O}_{2}$ generations from reduction of $\mathrm{O}_{2}{ }^{-}$and/or lysis of $\mathrm{H}_{2} \mathrm{O}_{2}$ by any nucleophilic reactions with $\mathrm{TiO}_{2}-\mathrm{NP}$. This was supported by other NP mediated direct oxidation of $\mathrm{H}_{2} \mathrm{O}_{2}$ following relieve the oxidative stress in crop species (Sharma et al., 2012).

Maize being a typical $\mathrm{C}_{4}$ species is worth of justification with carbon metabolism through minimized photo-respiratory loss of $\mathrm{CO}_{2}$. The elevation of carbon loss through photo-respiration under abiotic stresses is compensated by few reactions for re-fixation of $\mathrm{CO}_{2}$. NADP-ME is the key regulatory enzyme in oxidative decarboxylation of malate to release $\mathrm{CO}_{2}$ (Doubnerova \& Ryslava, 2011) Undoubtedly, oxidative stress would be more prone to damage the cellula membrane by ROS that may hamper the chloroplastic reactions mechanisms also. In $\mathrm{C}_{4}$ plants the high light compensation point would be more attributing to tolerate ROS either by development of anti-oxidation cascades or minimization of energy absorption (Yamori et al., 2014). Whatever the cases replenish more $\mathrm{CO}_{2}$ through oxidative decarboxylase like NADP-ME would be justified to study, particularly, with $\mathrm{TiO}_{2}-\mathrm{NP}$ interaction. Through the gradient of $\mathrm{H}_{2} \mathrm{O}_{2}$ concentration, maize plants in the present experiment has been able to sustain the activity of NADP-ME more with $\mathrm{TiO}_{2}-\mathrm{NP}$ application. Development of ROS and perturbed cellular redox are overcome by the $\mathrm{C}_{4}$ traits as observed in other $\mathrm{C}_{4}$ species (Keech $\boldsymbol{e t}$ al., 2017). This agrees with the present experiment that by $\mathrm{TiO}_{2}$-NP moderation to circumvent re-generation of $\mathrm{CO}_{2}$ by NADP-ME reactions. $\mathrm{TiO}_{2}-\mathrm{NP}$ documented to induce the release of $\mathrm{CO}_{2}$ from organic acids pool. This otherwise supports the anaplerotic reactions leading to more acquisition of reduced carbon. The later is required for allocation of carbon in other residues like anti-oxidants, compatible solutes, storage compounds, signalling molecules etc to support tolerance (Gomez-Merino \& Trejo-Tellez, 2018)

Tolerance to oxidative stress is much ahead for a $\mathrm{C}_{4}$ species with demarcation of tissues where photorespiratory loss are minimized. Still, NP would be more interesting as revealed from the present experiment where a significant modulation of anti-oxidation was the results. A significant accumulation of $\mathrm{H}_{2} \mathrm{O}_{2}$ and $\mathrm{O}_{2}^{--}$undoubtedly proved the genotoxicity and opens the probability for $\mathrm{TiO}_{2}$ $\mathrm{NP}$ interaction. $\mathrm{TiO}_{2}$-NP mediated stress response is not much frequent except in few cases. However, in cotton the peroxidase activity was markedly induced under salinity stress (Meloni $\boldsymbol{e t}$ al., 2003). The signal for salinity happens to be amplified by $\mathrm{TiO}_{2}$ as a semi-conductor through the cellular system. The interactions of $\mathrm{TiO}_{2}$-NP either to de-novo synthesis of anti-oxidative proteins or to induce a hyper-activity that favoured to maintain an adequate redox. Therefore, significant changes of GPX activity would be more contributing to lysis of $\mathrm{H}_{2} \mathrm{O}_{2}$ of the bio-molecules before it is converted to other radicals. Thus, the activity of GPX through on-going $\mathrm{H}_{2} \mathrm{O}_{2}$ concentration and more with $\mathrm{TiO}_{2-}$ $\mathrm{NP}$ induction is hopeful to support for tolerance. This could be more pruden where polymorphisms of GPX was recorded varying band intensities in the present case. The polymorphic band intensities adhered to their expression tissue specifically have also mentioned in many crops as well as non-crops plant species against xenobiotic toxicity (Rout et al., 2019). Moreover, these variations in protein content from different isozymes is expected to set more complexity for $\mathrm{TiO}_{2}-\mathrm{NP}$ induction under $\mathrm{H}_{2} \mathrm{O}_{2}$ treatment. The over expression of peroxidase with nano-material in plants is supposed to have two consequences. In general, nanomaterial itself as a xenobiotic can induce oxidative stress and thus the expression would be marked tolerant strategies. In addition, the interaction with $\mathrm{TiO}_{2}-\mathrm{NP}$ as a semiconductor might have changed the redox potential of the tissues following membrane functions. Electrons carrier proteins on membrane are quite sensitive to any changes of redox and thereby ensures the dismutations of oxygen into superoxide, peroxides etc. For mitigation of superoxide plant potential to induce few variants of enzyme activity has been supportive in selection of genotypes (Kubis, 2008). Moreover, the modulation of such an expression under any chemical elicitations would be expecting its steering role both at gene transcription and translational level. The present study where an induction with $\mathrm{TiO}_{2} \mathrm{NP}$ consistently improvised through $\mathrm{H}_{2} \mathrm{O}_{2}$ stress is quite interesting. On the other hand, the initiation of ROS through over reduction of molecular $\mathrm{O}_{2}$ by electron is regulated by SOD activity. It is interesting to note that maize plants in the present experiment were more lenient to exercise the $\mathrm{TiO}_{2}-\mathrm{NP}$ in a dose dependent manner. Up-regulation of SOD kinetics in support of cellular defense has also been documented in few nano-materials like cadmium sulphide etc (Tang et al., 2015). This is a good exercise that nano-material would be more adjusted on the onset of oxidative stress by over-expression of SOD before it is converted into others like $\mathrm{OH}^{-}, \mathrm{OH}^{-}$etc. A depletion of redox and its retrieval through glutathione is common regardless of crop species (Jozefczak $\boldsymbol{e t}$ al. 2012). Therefore, glutathione metabolising enzymes like GR would be important Through the course of $\mathrm{H}_{2} \mathrm{O}_{2}, \mathrm{TiO}_{2}-\mathrm{NP}$ has been up-regulatory except under $100 \mu \mathrm{M} \mathrm{H}_{2} \mathrm{O}_{2}$. This may limit a threshold value for induction of glutathione with its turn-over in its reduced form. Therefore, nanoparticle is also evident with its discretion to favour anti-oxidation in differential modes (Rico et al., 2013). It would also be speculated at higher concentration of $\mathrm{H}_{2} \mathrm{O}_{2}$ or other related effectors, nano materials would also be itself restraining to moderate the oxidative stress. On the other hand, a discriminatory role of CAT is played under same condition where a linear fall of activity through $\mathrm{H}_{2} \mathrm{O}_{2}$ treatment were recorded. But the activity was up-regulated when $\mathrm{TiO}_{2}-\mathrm{NP}$ was applied as pretreatment. The discriminating behaviour of CAT activity either function of concentration of stressors has well been justified in cereal like rice (Nounjan $\boldsymbol{e}$ al., 2012). It is the concentration dependence for any gene to adapt any inducer as promotive or repressive in nature was nicely justified with CAT. A prediction for down regulation of CAT activity would be referred both by inhibited de-novo synthesis of the enzyme protein or/and a static binding with any inhibitors (Michelet et al., 2013). $\mathrm{TiO}_{2}-\mathrm{NP}$ might have equal possibility either to induce the transcripts for CAT or erasing the inhibition from CAT regulatory sites (Rico et al., 2013). Thus, $\mathrm{TiO}_{2}-\mathrm{NP}$ with its best possibilities would be resourceful to ameliorate the impact of oxidative stress in $\mathrm{C}_{4}$ plants as established with the maize system in the present case.

\section{CONCLUSION}

The present paper represents the documentation of $\mathrm{C}_{4}$ module in response to oxidative stress through $\mathrm{H}_{2} \mathrm{O}_{2}$ exposure with maize species. The responses of plants to $\mathrm{H}_{2} \mathrm{O}_{2}$ induced oxidative stress is dose dependent. $\mathrm{C}_{4}$ module has an inbuilt improved anti-oxidation strategy which goes over expressed with $\mathrm{TiO}_{2}-\mathrm{NP}$ application for both ROS and anti-oxidation cascades. It is evident that $\mathrm{TiO}_{2}-\mathrm{NP}$ is most bio-compatible, at least in maize in the present experiment. Therefore, $\mathrm{TiO}_{2}$-NP itself being a xenobiotic could also interact with $\mathrm{C}_{4}$ system to ameliorate the oxidative stress. So, any formulation with metal nanoparticlebased system is expected to be lenient in recovery of stress tolerance through $\mathrm{C}_{4}$ module. This paper is expected to deliver two lines of expectations: the use of $\mathrm{TiO}_{2}-\mathrm{NP}$ through $\mathrm{C}_{4}$ modules for evoking the anti-oxidation potential and that could be exercise by others $\mathrm{C}_{4}$ crop species to mitigate related abiotic stresses.

Acknowledgements: The first author, Mr. Bipul Sarkar is acknowledges for his NET JRF Fellowship Scheme to execute the research work supported by University Grant Commission (UGC), Govt. of India. This work is also acknowledged for financial support by Department of Science and Technologythrough DST-PURSE II programme, Govt. of India applicable to University of Kalyani.

\section{REFERENCES}

Ahmad, P., Sarwat, M., \& Sharma, S. (2008). Reactive oxygen species, antioxidants and signaling in plants. Journal of Plant Biology, 51(3), 167-173. https://doi.org/10.1007/BF03030694

Almeselmani, M., Deshmukh, P. S., Sairam, R. K., Kushwaha, S. R., \& Singh, T. P. (2006). Protective role of antioxidant enzymes under high temperature stress. Plant science, 171(3), 382-388. https://doi.org/10.1016/j.plantsci.2006.04.009 Ammar, W. B., Nouairi, I., Zarrouk, M., Ghorbel, M. H., \& Jemal, F. (2008). Antioxidative response to cadmium in roots and leaves of tomato plants. Biologia Plantarum, 52(4), 727. https://doi.org/10.1007/s10535-008-0140-2

Baig, J. A., Kazi, T. G., Shah, A. Q., Arain, M. B., Afridi, H. I., Khan, S., ... \& Soomro, A. S. (2010). Evaluating the accumulation of arsenic in maize (Zea mays L.) plants from its growing media by cloud point extraction. Food and Chemical Toxicology, 48(11), 3051-3057. https://doi.org/10.1016/j.fct.2010.07.043

Bates, L. S., Waldren, R. P., \& Teare, I. D. (1973). Rapid determination of free proline for water-stress studies. Plant and soil, 39(1), 205207. https://doi.org/10.1007/BF00018060

Bauwe, H. (2010). Photorespiration: the bridge to $\mathrm{C}_{4}$ photosynthesis. In $\mathrm{C}_{4}$ photosynthesis and related $\mathrm{CO}_{2}$ concentrating mechanisms (pp. 81-108) Springer, Dordrecht. https://doi.org/10.1007/978-90-481-9407-0_6

Bradford, M. M. (1976). A rapid and sensitive method for the quantitation of microgram quantities of protein utilizing the principle of protein-dye binding. Analytical biochemistry, 72(1-2), 248-254. https://doi.org/10.1016/00032697(76)90527-3

Cakmak, I., \& Marschner, H. (1992). Magnesium deficiency and high light intensity enhance activities of superoxide dismutase, ascorbate peroxidase, and glutathione reductase in bean leaves. Plant physiology, 98(4), 1222-1227 https://doi.org/10.1104/pp.98.4.1222 
Catalá, A. (2009). Lipid peroxidation of membrane phospholipids generates hydroxy-alkenals and oxidized phospholipids active in physiological and/or pathological conditions. Chemistry and physics of lipids, 157(1), 1-11. https://doi.org/10.1016/j.chemphyslip.2008.09.004

Das, K., \& Roychoudhury, A. (2014). Reactive oxygen species (ROS) and response of antioxidants as ROS-scavengers during environmental stress in plants. Frontiers in Environmental Science, 2, 53 https://doi.org/10.3389/fenvs.2014.00053

De, A.K., Ghosh, A., Debnath, S.C., Sarkar, B., Saha, I., Adak, M.K. (2018) Modulation of physiological responses with $\mathrm{TiO}_{2}$ nano-particle in Azolla pinnata R. Br under 2,4-D toxicity. Mol Biol Rep. https://doi.org/10.1007/s11033-0184203-y

Doubnerová, V., \& Ryšlavá, H. (2011). What can enzymes of $\mathrm{C}_{4}$ photosynthesis do for $\mathrm{C}_{3}$ plants under stress?. Plant Science, 180(4), 575-583 https://doi.org/10.1016/j.plantsci.2010.12.005

Duhan, J. S., Kumar, R., Kumar, N., Kaur, P., Nehra, K., \& Duhan, S. (2017). Nanotechnology: The new perspective in precision agriculture. Biotechnology Reports, 15, 11-23. https://doi.org/10.1016/j.btre.2017.03.002

Elstner, E. F., \& Heupel, A. (1976). Inhibition of nitrite formation from hydroxylammoniumchloride: a simple assay for superoxide dismutase. Analytica biochemistry, 70(2), 616-620. https://doi.org/10.1016/0003-2697(76)90488-7

Fryer, M. J., Oxborough, K., Mullineaux, P. M., \& Baker, N. R. (2002). Imaging of photo-oxidative stress responses in leaves. Journal of experimental botany, 53(372), 1249-1254. https://doi.org/10.1093/jexbot/53.372.1249

Giannopolitis, C. N., \& Ries, S. K. (1977). Superoxide dismutases: Occurrence in higher plants. Plant physiology, 59(2), 309-314. https://doi.org/10.1104/pp.59.2.309

Gómez-Merino, F. C., \& Trejo-Téllez, L. I. (2018). The Role of Beneficia Elements in Triggering Adaptive Responses to Environmental Stressors and Improving Plant Performance. In Biotic and Abiotic Stress Tolerance in Plant (pp. 137-172). Springer, Singapore. https://doi.org/10.1007/978-981-10-9029-5_6 Goodarzi, G. R., Noor, V. P., \& Ahmadloo, F. (2017). Effects of nanoparticle treatments on propagation of Prunus mahaleb L. by seed. Journal of Forest Science, 63(9), 408-416. https://doi.org/10.17221/18/2017-JFS

Gupta, D. K., Palma, J. M., \& Corpas, F. J. (Eds.). (2016). Redox state as a central regulator of plant-cell stress responses. Springer. https://doi.org/10.1007/978-3-319-44081-1

Heath, R. L., \& Packer, L. (1968). Photoperoxidation in isolated chloroplasts: Kinetics and stoichiometry of fatty acid peroxidation. Archives of biochemistry and biophysics, 125(1), 189-198. https://doi.org/10.1016/0003-9861(68)90654-1 Jozefczak, M., Remans, T., Vangronsveld, J., \& Cuypers, A. (2012). Glutathione is a key player in metal-induced oxidative stress defenses. International journal of molecular sciences, 13(3), 3145-3175. https://doi.org/10.3390/ijms13033145 Karuppanapandian, T., Moon, J. C., Kim, C., Manoharan, K., \& Kim, W. (2011) Reactive oxygen species in plants: their generation, signal transduction, and scavenging mechanisms. Australian Journal of Crop Science, 5(6), 709 https://search.informit.com.au/documentSummary; $\mathrm{dn}=282079847301776$;res=IE LHSS

Kavi Kishor, P. B., \& Sreenivasulu, N. (2014). Is proline accumulation per se correlated with stress tolerance or is proline homeostasis a more critical issue? Plant, cell \& environment, 37(2), 300-311. https://doi.org/10.1111/pce.12157 Keech, O., Gardeström, P., Kleczkowski, L. A., \& Rouhier, N. (2017). The redox control of photorespiration: from biochemical and physiological aspects to biotechnological considerations. Plant, cell \& environment, 40(4), 553-569. https://doi.org/10.1111/pce.12713

Kubiś, J. (2008). Exogenous spermidine differentially alters activities of some scavenging system enzymes, $\mathrm{H}_{2} \mathrm{O}_{2}$ and superoxide radical levels in water-stressed cucumber leaves. Journal of Plant Physiology, 165(4), 397-406 https://doi.org/10.1016/j.jplph.2007.02.005

Liu, H., Ma, C., Chen, G., White, J. C., Wang, Z., Xing, B., \& Dhankher, O. P. (2017). Titanium dioxide nanoparticles alleviate tetracycline toxicity to Arabidopsis thaliana (L.). ACS Sustainable Chemistry \& Engineering, 5(4), 3204-3213. https://doi.org/10.1021/acssuschemeng.6b02976

Lu, Z., \& Neumann, P. M. (1998). Water-stressed maize, barley and rice seedlings show species diversity in mechanisms of leaf growth inhibition. Journa of Experimental Botany, 49(329), 1945-1952. https://doi.org/10.1093/jxb/49.329.1945

Mandal, C., Bera, S., Dey, N., \& Adak, M. (2016). Physiological alterations of Salvinia natans $\mathrm{L}$. exposed to aluminium stress and its interaction with polyamine. Plant Science Today, 3(2), 195-206. https://doi.org/10.14719/pst.2016.3.2.198

Mano, J. I. (2012). Reactive carbonyl species: their production from lipid peroxides, action in environmental stress, and the detoxification mechanism. Plant Physiology and Biochemistry, 59, 90-97. https://doi.org/10.1016/j.plaphy.2012.03.010

Meloni, D. A., Oliva, M. A., Martinez, C. A., \& Cambraia, J. (2003) Photosynthesis and activity of superoxide dismutase, peroxidase and glutathione reductase in cotton under salt stress. Environmental and Experimental Botany, 49(1), 69-76. https://doi.org/10.1016/S0098-8472(02)00058-8
Michelet, L., Roach, T., Fischer, B. B., Bedhomme, M., Lemaire, S. D., \& Krieger-Liszkay, A. N. J. A. (2013). Down-regulation of catalase activity allows transient accumulation of a hydrogen peroxide signal in Chlamydomona reinhardtii. Plant, Cell \& Environment, 36(6), 1204-1213. https://doi.org/10.1111/pce.12053

Morteza, E., Moaveni, P., Farahani, H. A., \& Kiyani, M. (2013). Study of photosynthetic pigments changes of maize (Zea mays L.) under nano $\mathrm{TiO}_{2}$ spraying at various growth stages. Springer Plus, 2(1), 247 https://doi.org/10.1186/2193-1801-2-247

Murashige, T., \& Skoog, F. (1962). A revised medium for rapid growth and bio assays with tobacco tissue cultures. Physiologia plantarum, 15(3), 473-497. https://doi.org/10.1111/j.1399-3054.1962.tb08052.x

Murmu, J., Chinthapalli, B., \& Raghavendra, A. S. (2003). Light activation of NADP malic enzyme in leaves of maize: marginal increase in activity, but marked change in regulatory properties of enzyme. Journal of plant physiology, 160(1), 51-56. https://doi.org/10.1078/0176-1617-00844

Nounjan, N., Nghia, P. T., \& Theerakulpisut, P. (2012). Exogenous proline and trehalose promote recovery of rice seedlings from salt-stress and differentially modulate antioxidant enzymes and expression of related genes. Journal of plant physiology, 169(6), 596-604. https://doi.org/10.1016/j.jplph.2012.01.004

Petrov, V. D., \& Van Breusegem, F. (2012). Hydrogen peroxide-a central hub for information flow in plant cells. AoB plants, 2012 https://doi.org/10.1093/aobpla/pls014

Prasad, R., Gupta, N., Kumar, M., Kumar, V., Wang, S., \& Abd-Elsalam, K. A (2017). Nanomaterials act as plant defense mechanism. In Nanotechnology (pp. 253-269). Springer, Singapore. https://doi.org/10.1007/978-981-10-4678-0 14 Quan, L. J., Zhang, B., Shi, W. W., \& Li, H. Y. (2008). Hydrogen peroxide in plants: a versatile molecule of the reactive oxygen species network. Journal of Integrative Plant Biology, 50(1), 2-18. https://doi.org/10.1111/j.1744 7909.2007.00599.x

Raven, J. A., Handley, L. L., \& Wollenweber, B. (2004). Plant nutrition and water use efficiency. Water use efficiency in plant biology, 171-197.

Rico, C. M., Morales, M. I., McCreary, R., Castillo-Michel, H., Barrios, A. C. Hong, J. \& Gardea-Torresdey, J. L. (2013). Cerium oxide nanoparticles modify the antioxidative stress enzyme activities and macromolecule composition in rice seedlings. Environmental science \& technology, 47(24), 14110-14118 https://doi.org/10.1021/es4033887

Rout, J. R., Kerry, R. G., Panigrahi, D., Sahoo, S. L., Pradhan, C., Ram, S. S., .. \& Sudarshan, M. (2019). Biochemical, molecular, and elemental profiling of Withania somnifera L. with response to zinc stress. Environmental Science and Pollution Research, 26(4), 4116-4129. https://doi.org/10.1007/s11356-018-3926

Sarkar, B., De, A. K., \& Adak, M. K. (2017). Physiological characterization of SUB1 trait in rice under subsequent submergence and re-aeration with interaction of chemical elicitors. Plant Science Today, 4(4), 177-190. https://doi.org/10.14719/pst.2017.4.4.351 Schützendübel, A., Nikolova, P., Rudolf, C., \& Polle, A. (2002). Cadmium and $\mathrm{H}_{2} \mathrm{O}_{2}$-induced oxidative stress in Populus $\times$ canescens roots. Plant Physiology and Biochemistry, 40(6-8), 577-584 https://doi.org/10.1016/S0981-9428(02)01411-0

Sharma, P., Bhatt, D., Zaidi, M. G. H., Saradhi, P. P., Khanna, P. K., \& Arora, S. (2012). Silver nanoparticle-mediated enhancement in growth and antioxidan status of Brassica juncea. Applied biochemistry and biotechnology, 167(8), 2225-2233. https://doi.org/10.1007/s12010-012-9759-8

Stepien, P., \& Klobus, G. (2005). Antioxidant defense in the leaves of $\mathrm{C}_{3}$ and $\mathrm{C}_{4}$ plants under salinity stress. Physiologia Plantarum, 125(1), 31-40. https://doi.org/10.1111/j.1399-3054.2005.00534.X

Tang, S., Wu, Y., Ryan, C. N., Yu, S., Qin, G., Edwards, D. S., \& Mayer, G. D. (2015). Distinct expression profiles of stress defense and DNA repair genes in Daphnia pulex exposed to cadmium, zinc, and quantum dots. Chemosphere, 120 92-99. https://doi.org/10.1016/j.chemosphere.2014.06.011

Thaler, J. S., Fidantsef, A. L., Duffey, S. S., \& Bostock, R. M. (1999). Trade-off in plant defense against pathogens and herbivores: a field demonstration of chemical elicitors of induced resistance. Journal of Chemical Ecology, 25(7), 1597-1609. https://doi.org/10.1023/A:1020840900595

Thordal-Christensen, H., Zhang, Z., Wei, Y., \& Collinge, D. B. (1997). Subcellular localization of $\mathrm{H}_{2} \mathrm{O}_{2}$ in plants. $\mathrm{H}_{2} \mathrm{O}_{2}$ accumulation in papillae and hypersensitive response during the barley-powdery mildew interaction. The Plant Journal, 11(6), 1187-1194. https://doi.org/10.1046/j.1365 313X.1997.11061187.x

Velikova, V., Yordanov, I., \& Edreva, A. (2000). Oxidative stress and some antioxidant systems in acid rain-treated bean plants: protective role of exogenous polyamines. Plant science, 151(1), 59-66. https://doi.org/10.1016/S0168 9452(99)00197-1

Verbeke, P., Siboska, G. E., Clark, B. F., \& Rattan, S. I. (2000). Kinetin inhibits protein oxidation and glycoxidation in-vitro. Biochemical and biophysical research communications,

https://doi.org/10.1006/bbrc.2000.3616

276(3),

$1265-1270$.

Verma, S., \& Dubey, R. S. (2003). Lead toxicity induces lipid peroxidation and alters the activities of antioxidant enzymes in growing rice plants. Plant Science, 164(4), 645-655. https://doi.org/10.1016/S0168-9452(03)00022-0 
Yamori, W., Hikosaka, K., \& Way, D. A. (2014). Temperature response of photosynthesis in $\mathrm{C}_{3}, \mathrm{C}_{4}$, and CAM plants: temperature acclimation and temperature adaptation. Photosynthesis research, 119(1-2), 101-117. https://doi.org/10.1007/s11120-013-9874-6 Yaqoob, S., Ullah, F., Mehmood, S., Mahmood, T., Ullah, M., Khattak, A., \& Zeb, M. A. (2018). Effect of waste water treated with $\mathrm{TiO}_{2}$ nanoparticles on early seedling growth of Zea mays L. Journal of Water Reuse and Desalination, 8(3), 424-431. https://doi.org/10.2166/wrd.2017.163

Zahra, Z., Waseem, N., Zahra, R., Lee, H., Badshah, M. A., Mehmood, A., ... \& Arshad, M. (2017). Growth and metabolic responses of rice (Oryza sativa L.) cultivated in phosphorus-deficient soil amended with $\mathrm{TiO}_{2}$ nanoparticles. Journal of agricultural and food chemistry, 65(28), 5598-5606. https://doi.org.10.1021/acs.jafc.7b01843

Zhao, L., Peng, B., Hernandez-Viezcas, J. A., Rico, C., Sun, Y., Peralta-Videa, J. R., ... \& Zhang, J. Y. (2012). Stress response and tolerance of Zea mays to $\mathrm{CeO}_{2}$ nanoparticles: cross talk among $\mathrm{H}_{2} \mathrm{O}_{2}$, heat shock protein, and lipid peroxidation. ACS nano, 6(11), 9615-9622. https://doi.org.10.1021/nn302975u 